\title{
Combined Heat and Power in Mexico: Market Opportunity Analysis
}

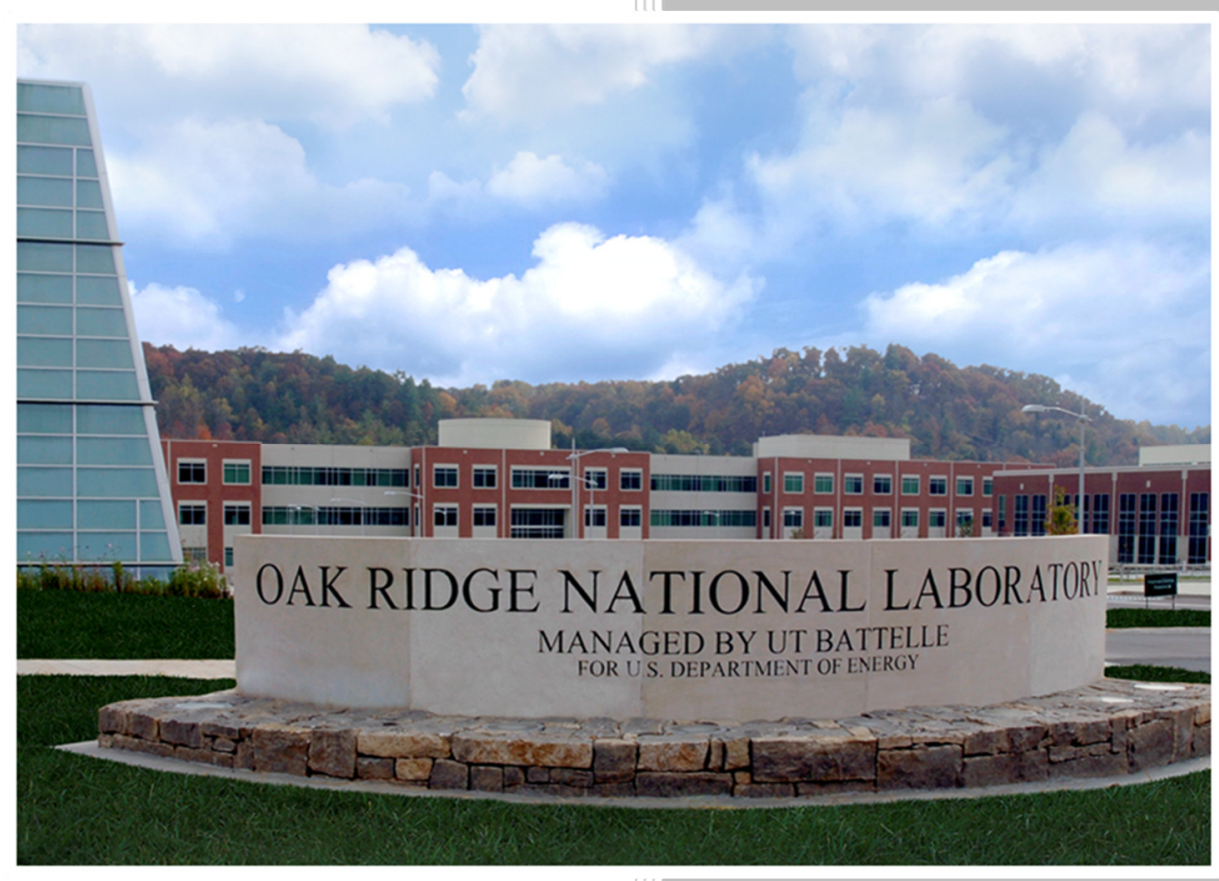

\section{Approved for public release.} Distribution is unlimited.

Kristina O. Armstrong

Bruce Hedman

Thomas Wenning Jorge Gutiérrez Elena Berger Patricia Garland

August 2018 


\section{DOCUMENT AVAILABILITY}

Reports produced after January 1, 1996, are generally available free via US Department of Energy (DOE) SciTech Connect.

Website www.osti.gov

Reports produced before January 1, 1996, may be purchased by members of the public from the following source:

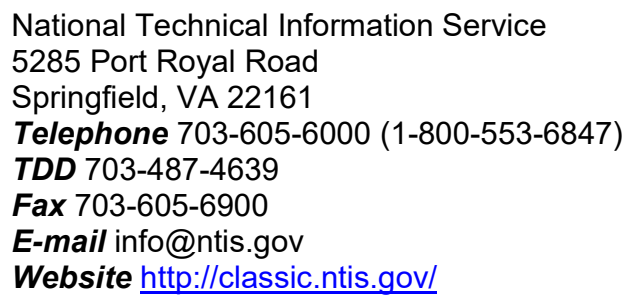

Reports are available to DOE employees, DOE contractors, Energy Technology Data Exchange representatives, and International Nuclear Information System representatives from the following source:

Office of Scientific and Technical Information

PO Box 62

Oak Ridge, TN 37831

Telephone 865-576-8401

Fax 865-576-5728

E-mail reports@osti.gov

Website http://www.osti.gov/contact.html

This report was prepared as an account of work sponsored by an agency of the United States Government. Neither the United States Government nor any agency thereof, nor any of their employees, makes any warranty, express or implied, or assumes any legal liability or responsibility for the accuracy, completeness, or usefulness of any information, apparatus, product, or process disclosed, or represents that its use would not infringe privately owned rights. Reference herein to any specific commercial product, process, or service by trade name, trademark, manufacturer, or otherwise, does not necessarily constitute or imply its endorsement, recommendation, or favoring by the United States Government or any agency thereof. The views and opinions of authors expressed herein do not necessarily state or reflect those of the United States Government or any agency thereof. 
Energy and Transportation Science Division

\title{
COMBINED HEAT AND POWER IN MEXICO: MARKET OPPORTUNITY ANALYSIS
}

\author{
Kristina O. Armstrong \\ Bruce Hedman* \\ Thomas Wenning \\ Jorge Gutiérrez** \\ Elena Berger*** \\ Patricia Garland $* * * *$
}

\footnotetext{
*Entropy Research, LLC, Alexandria, VA

** Cogenera Mexico

*** U.S. Department of Energy

**** Oak Ridge National Laboratory - Retired
}

August 2018

Prepared by

OAK RIDGE NATIONAL LABORATORY

Oak Ridge, TN 37831-6283

managed by

UT-BATTELLE, LLC

for the

US DEPARTMENT OF ENERGY

under contract DE-AC05-00OR22725 



\section{CONTENTS}

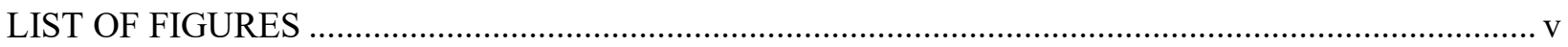

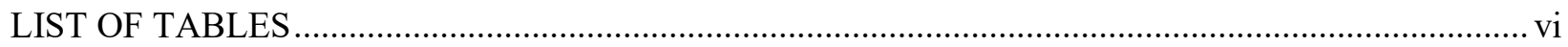

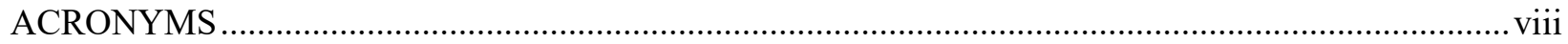

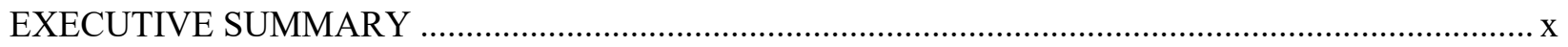

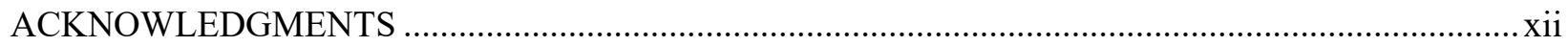

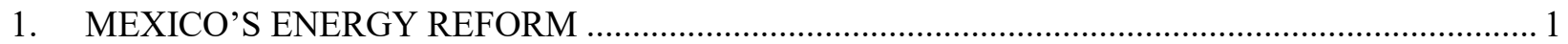

1.1 CONSTITUTIONAL REFORMS AND ENERGY LEGISLATION BENEFITING CHP ....... 1

1.1.1 Oil and Natural Gas Sector Reform ................................................................. 1

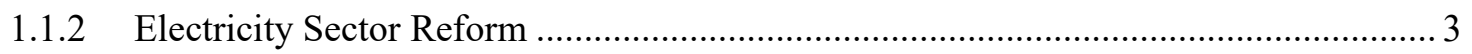

1.1.3 Other Reforms and Regulations Impacting CHP ............................................... 4

1.2 OVERVIEW OF THE REGULATORY STRUCTURE ASSOCIATED WITH CHP .............. 4

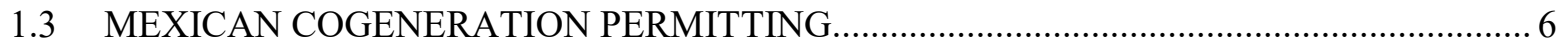

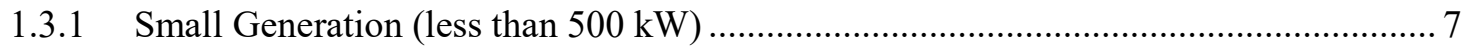

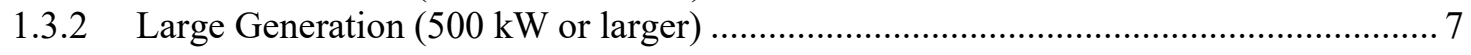

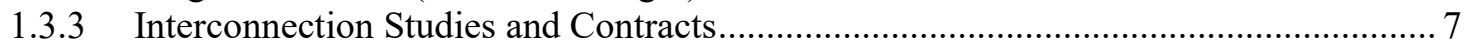

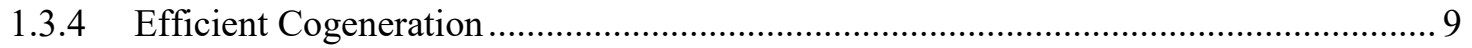

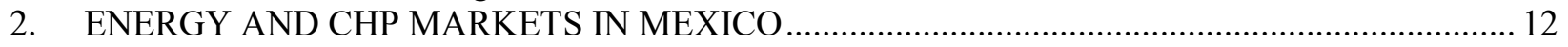

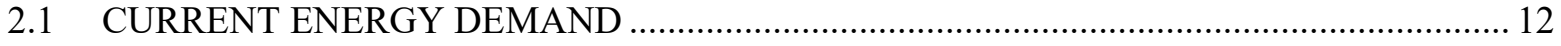

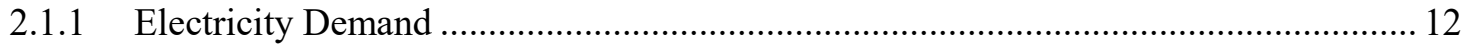

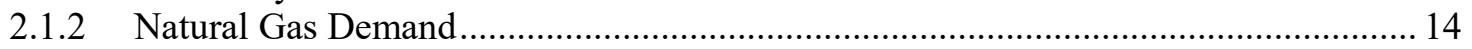

2.2 CHP INSTALLED CAPACITY AND APPLICATIONS AND CURRENT MARKET

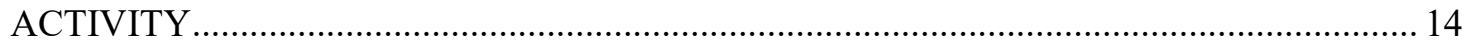

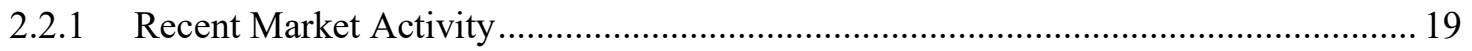

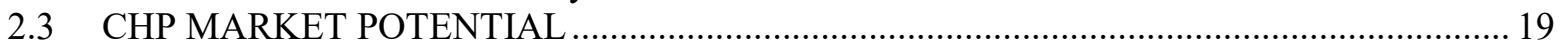

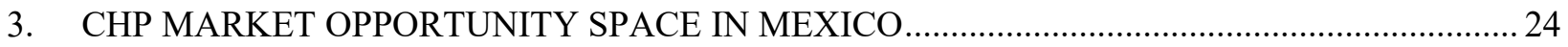

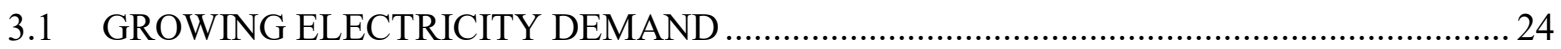

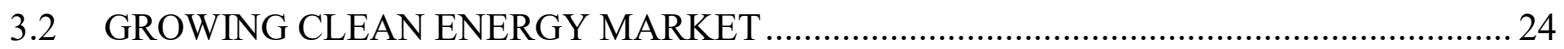

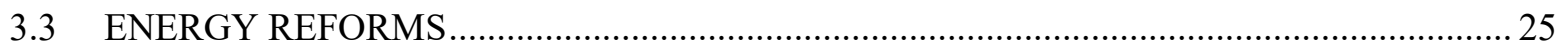

3.4 OTHER SECTORS: SUGAR, COMMERCIAL, DATA CENTERS, OFF-GRID .................. 25

3.5 MODES OF ENTRANCE FOR CHP DEVELOPERS AND POWER PRODUCERS ............ 26

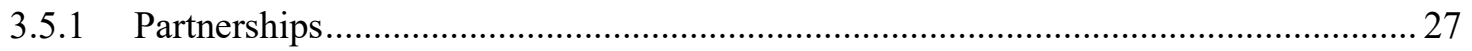

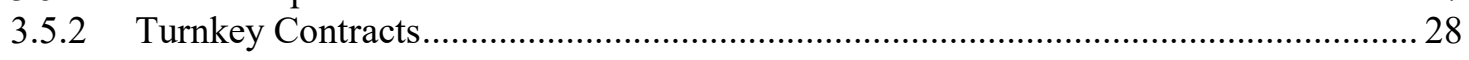

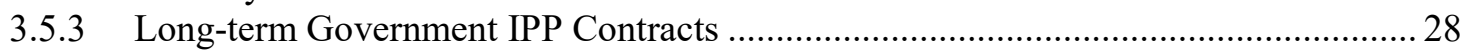

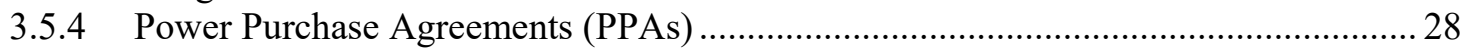

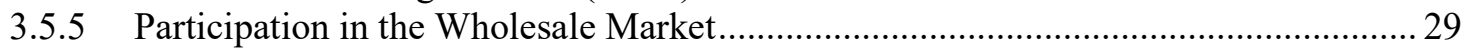

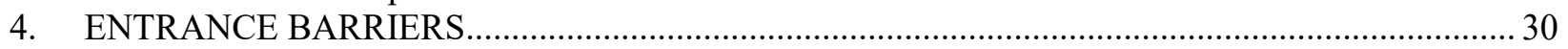

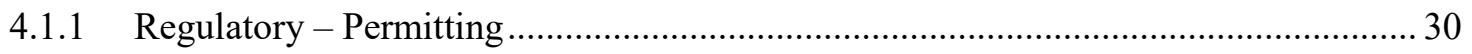

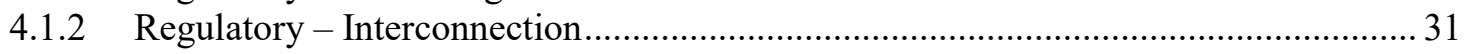

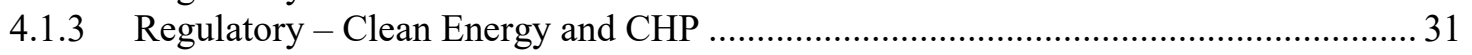

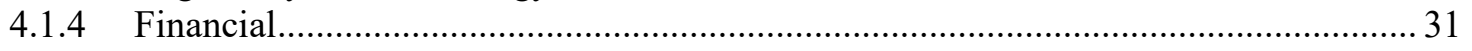

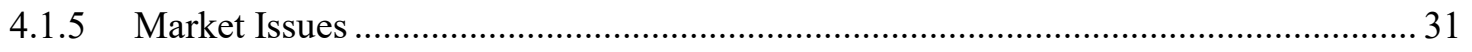

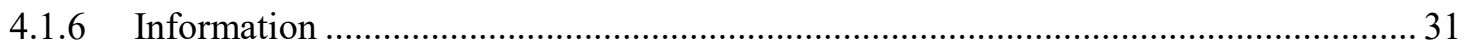

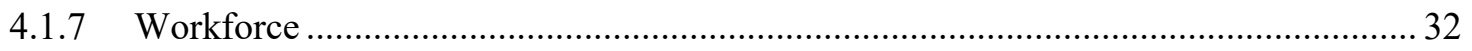

5. MEXICAN GOVERNMENT PROGRAMS, RESOURCES, AND INCENTIVES .......................... 33

5.1 INVESTMENT GUIDANCE FOR FOREIGN COMPANIES …...................................... 33

5.2 TAX INCENTIVES AND FINANCING MECHANISMS ............................................... 33

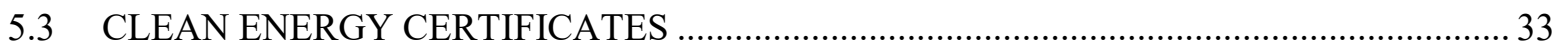

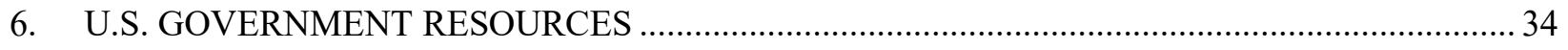




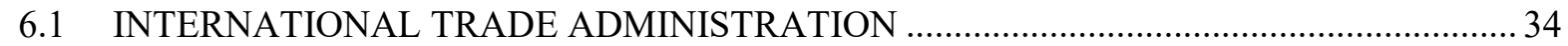

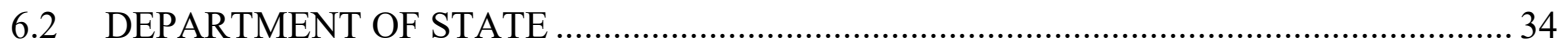

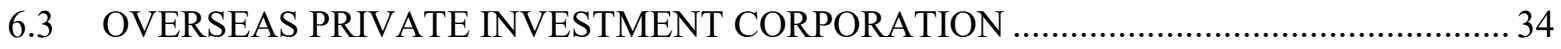

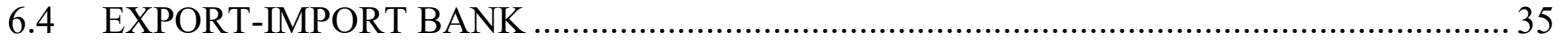

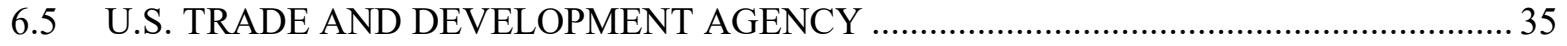

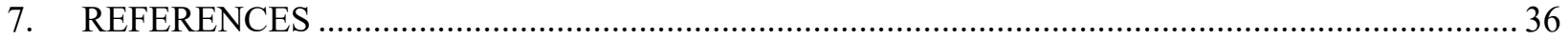

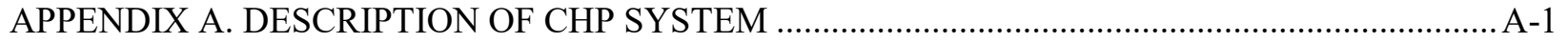
APPENDIX B. FORMS AND DOCUMENTATION NEEDED TO GAIN A PERMIT FOR ELECTRICITY GENERATION, EFFICIENT COGENERATION ACCREDITATION, AND

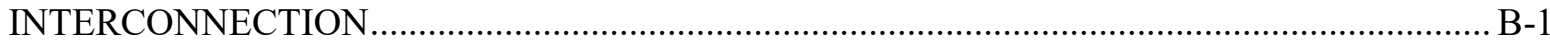
APPENDIX C. CONTACTS IN KEY ORGANIZATIONS ............................................................. C-7 


\section{LIST OF FIGURES}

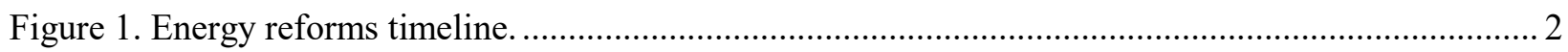

Figure 2. Governmental bodies of the Mexican energy sector. ....................................................... 4

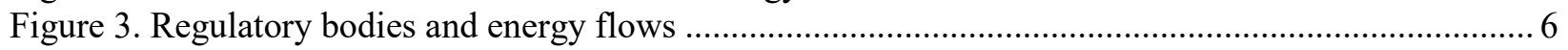

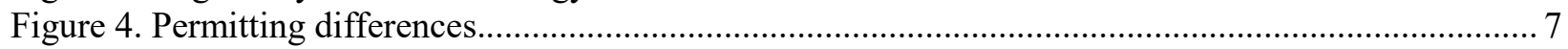

Figure 5. Actual and predicted generation (TWh) segregated by generation technology ......................... 12

Figure 6. Breakdown of Mexican energy generation capacity by fuel ..................................................... 13

Figure 7. Mexican actual and forecast electricity consumption............................................................ 13

Figure 8. Mexican natural gas actual and planned pipelines ................................................................ 14

Figure 9. Annual count of cogeneration permits granted and have since been classified as efficient........ 15

Figure 10. Actual and predicted capacity (MW) segregated by generation technology ........................... 15

Figure 11. Fraction of CHP capacity (Mordor Intelligence 2017) compared to national electricity (Secretaría de Energía de México 2017a) and energy use .......................................................... 16

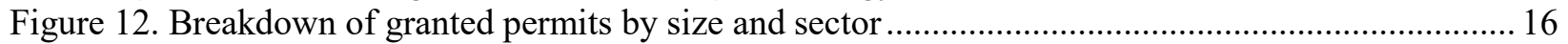

Figure 13. Capacity breakdown of granted permits by size and industrial sector ................................... 17

Figure 14. Distribution of all operational cogeneration permits .......................................................... 18

Figure 15. Case study - Capstone..................................................................................................... 19

Figure 16. Count and capacity of all issued cogeneration and efficient cogeneration permits by

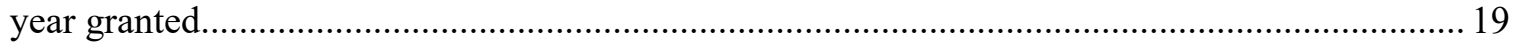

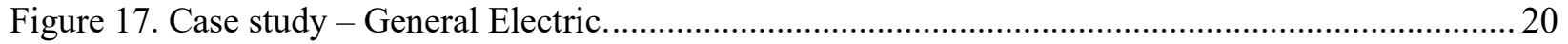

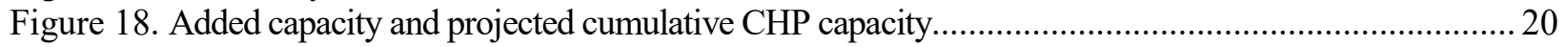

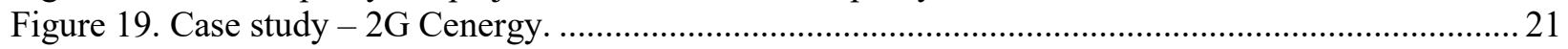

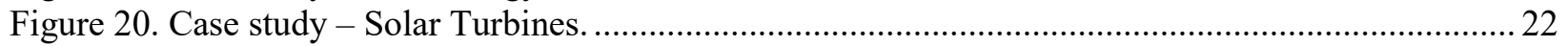

Figure 21. Comparison of CONUEE-GIZ study and cogeneration permits granted after 2009 ................ 22

Figure 22. Geographic distribution of industrial economic potential for cogeneration (in MW of

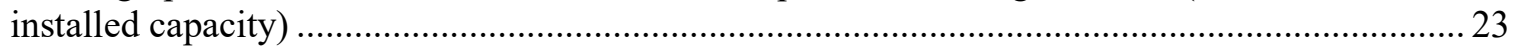

Figure 23: Geographic distribution of all cogeneration plants expected to come online between

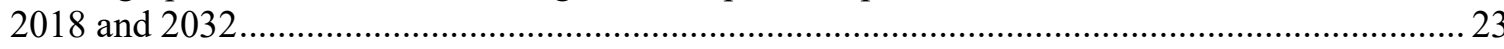

Figure 24. Legally mandated fraction of clean energy in the Mexican portfolio increasing to

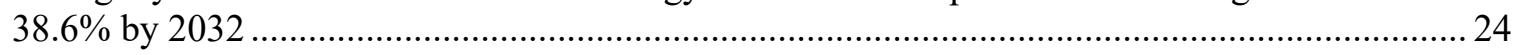

Figure 25. Modes of entrance for CHP developers and power producers. .............................................. 27 


\section{LIST OF TABLES}

Table 1. Cost in USD ( 1 Peso $=0.05336$ USD, 03-06-2018, not including VAT $)$ and total working days to carry out studies and deliver reports 8

Table 2. Forms required to obtain Efficient Accreditation. ............................................................ 9

Table 3. Length of accreditation for Efficient Accreditation .............................................................. 9

Table 4. Reference values (RefE and $R e f H)$ for calculation of Fuel-free Energy ................................... 10

Table 5. Reference values $(f p)$ for the calculation of fuel-free energy ................................................... 10

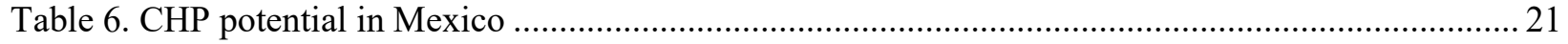

Table B.1. Online application form for a permit to generate electricity............................................. B-1

Table B.2. Online application form for a permit to generate electricity - additional documents............ B-2

Table B.3. Interconnection studies details. ........................................................................................ B-3

Table B.4. Form CRE-DGEER-011: Application for the permit holder of a cogeneration plant to obtain accreditation as efficient cogeneration..................................................................... B-3

Table B.5. Form CRE-DGEER-012: Application to authorize a person doing the measurement to

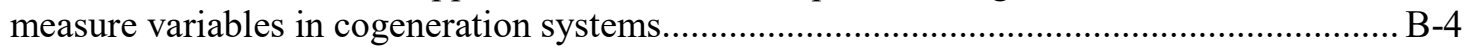

Table B.6. Form CRE-DGEER-013: Technical reporting format for parameters for the calculation of efficiency of cogeneration systems. 



\section{ACRONYMS}

CEL

CENACE

CENAGAS

CerPI

CFE

CHP

$\mathrm{CNH}$

CONUEE

CRE

DOS

EPC

Ex-Im

FIBRA E

FICAPs

GHG

GIZ

GTZ

HVDC

IPP

ITA

LFC

LIE

LTE

NAFTA

NGCC

OPIC

PEMEX

PPA

PRODESEN

PV

SEMARNAT

SEN

SENER

T\&D

USTDA
Clean Energy Certificates

Centro Nacional de Control de la Energía (National Center for Energy Control)

Centro Nacional de Control de Gas Natural (National Center of Control of Natural Gas)

Investment Project Certificate

Comisión Federal de Electricidad (Federal Electricity Commission)

Combined Heat and Power

Comisión Nacional de Hidrocarburos (National Hydrocarbons Commission)

Comisión Nacional para el Uso Eficiente de la Energia (National Commission for Efficient Energy Use)

Comisión Reguladora de Energía (Energy Regulatory Commission)

U.S. Department of State

Engineering, Procurement, and Construction

Export-Import Bank

Infrastructure and Real Estate Trusts

Investment Trusts for Private Capital

Greenhouse Gas

Deutsche Gesellschaft für Internationale Zusammenarbeit (GIZ) GmbH (German

Development Cooperation)

Gesellschaft für Technische Zusammenarbeit

High-Voltage Direct Current

Independent Power Producer

U.S. Department of Commerce's International Trade Administration

Luz y Fuerza del Centro

Electric Industry Law

Energy Transition Law

North American Free Trade Agreement

Natural Gas Combined-Cycle Systems

Overseas Private Investment Corporation

Mexican Petroleum

Power and Steam Purchase agreement

Programa de Desarrollo del Sistema Eléctrico Nacional

Photovoltaics

(Secretary of Environment and Natural Resources)

Sistema Eléctrico Nacional (National Electricity System)

Secretaria de Energía (Secretary of Energy)

Transmission and Distribution

U.S. Trade and Development Agency 



\section{EXECUTIVE SUMMARY}

Energy reforms in Mexico have emphasized the need for a more diversified energy portfolio to enhance energy security, decrease environmental degradation, and increase Mexico's economic competitiveness. Starting in 2013, these reforms provide new opportunities for the cogeneration of heat and power (also called combined heat and power, or CHP) in the following ways: (1) they include efficient CHP under clean electricity generation provisions, allowing them to generate Clean Energy Certificates (CEL); and (2) they facilitate investment and competition in natural gas, the primary fuel source of CHP, expanding access and reducing the price of gas, and increasing the competitive advantage of CHP.

Considering the changing regulatory environment in Mexico, and the potential opportunities offered to suppliers of CHP technologies, the U.S. Department of Energy commissioned a report to identify opportunities and challenges facing U.S. suppliers of CHP technology and services within the context of the current regulatory environment in Mexico. This report, prepared by the U.S. Department of Energy Oak Ridge National Laboratory, also provides an overview of the current energy policy environment and the electricity market dynamics related to the CHP sector in Mexico.

Mexico uses and generates around 300 TWh of electricity, mostly consumed by the industrial sector. Electricity demand is expected to grow by around 3\% per year for the next decade, calling the country to expand and modernize its electric grid. Clean energy accounts for $20 \%$ of the country's energy portfolio and should increase to $38.6 \%$ by 2032, per Mexican government targets (Secretaría de Energía de México 2018). Until recently, the federally owned company Comisión Federal de Electricidad (CFE) generated most of the electricity in the country. With recent reforms, the private sector now generates almost $30 \%$ of the electricity in Mexico. Natural gas is the most common electricity generation fuel and is especially common for CHP, making the reforms in the natural gas sector critical for the success of CHP in Mexico. The natural gas infrastructure is now more open to private investment.

As of April 2018, Mexico had approximately $4.4 \mathrm{GW}$ of CHP capacity (5.4\% of the total electrical capacity) operational, of which $30 \%$ has been given "Efficient Accreditation." CHP is heavily employed in the industrial sector, mostly in the oil and chemical industries. Despite recent increases in CHP installations, the market still has potential to grow; a 2009 market study estimated that there was over $10 \mathrm{GW}$ of CHP potential in the Mexican industrial sector (assuming excess electricity generation could be sold to CFE or other parties), which has not yet been achieved. Additionally, the commercial sector is the fastest growing energy consumer in Mexico; the sector itself is increasing as is the demand for cooling in the new and existing facilities. CHP can provide steam, hot water, and cooling to these facilities while maintaining a small footprint. Given these opportunities for CHP capacity, the official government energy plan, PRODESEN, expects future efficient cogeneration capacity to reach $3.63 \mathrm{GW}$ by 2032 .

The following factors contribute to growing opportunities for CHP developments in Mexico.

1. Electricity use and peak demand are growing.

2. Under the current regulations, CHP can fulfill the requirements for clean energy.

3. Reforms make it easier to sell excess electricity to the spot market and other electricity users.

4. Reforms facilitate private investment in natural gas pipelines.

5. There are several known sectors with unfulfilled cogeneration potential (sugar production, commercial, areas with no access to the grid). 
6. Reforms have added several modes of entrance into the energy market for power producers beyond self-generation and selling to the spot market.

While these opportunities could allow for increased investment in CHP, several barriers to implementing CHP projects remain. Many of the barriers pertain to difficulty finding up-to-date information on regulations regarding permitting, interconnection, and accreditation for efficient CHP. Additionally, there are barriers relating to obtaining financing, corporate support, and natural gas and electricity pricing and availability. Finally, there is also a general lack of pervasive knowledge about CHP and how to appropriately evaluate its benefits for feasibility studies. While these barriers may seem extensive, many can be overcome with access to more information and increased awareness of CHP.

This report is divided into six major sections that address the following issues and three appendices:

1. Mexican energy sector reforms and current regulatory structure;

2. the process for obtaining generation permits, accreditation for efficient $\mathrm{CHP}$, and interconnection to the grid;

3. market analysis of electricity, natural gas, and CHP in Mexico and case studies of US investments in CHP units in Mexico;

4. opportunities to expand CHP in the reformed Mexican energy market;

5. likely barriers to CHP installations; and

6. Mexican and U.S. government resources.

7. Appendices A-C provide a detailed description of a CHP system, permit forms and documentation needed for private investment, and contacts in key organizations. 


\section{ACKNOWLEDGMENTS}

The authors wish to thank the U.S. Department of Energy (DOE) for sponsorship and guidance on this work. The authors also appreciate the reviews and insights provided by Israel Jáuregui Nares (Comisión Nacional para el Uso Eficiente de la Energía, Mexico - CONUEE), Jen Derstine and Juan Mosseri (Capstone Turbine), Ulises Balestrini and Roberto Garcia (Solar Turbines), Grant Grothen and Noé Sáenz (Burns \& McDonnell), Claudia Salgado and Braeden Young (U.S. Foreign Commercial Service), Ramon Escobar (U.S. Embassy, Mexico), Victoria Gunderson and Leslie Wilson (US Department of Commerce), Craig O’Connor (Export-Import Bank of the United States), Nadia Rhazi (Overseas Private Investment Corporation), Andrew Graves (Department of Energy), and Vivek Hari (Oak Ridge National Laboratory). 



\section{MEXICO'S ENERGY REFORM}

\subsection{CONSTITUTIONAL REFORMS AND ENERGY LEGISLATION BENEFITING CHP}

Energy reforms brought competition to the long-closed oil, gas, and electricity sectors in Mexico (Figure 1). During the reform process, the Mexican government emphasized the need for a more diversified energy portfolio to enhance energy security, decrease environmental degradation, and increase Mexico's economic competitiveness. For over 75 years, Mexico's two state-owned energy conglomerates, Mexican Petroleum (PEMEX), the national oil company, and the Federal Electricity Commission (CFE), the electric utility, enjoyed a monopoly over the country's energy markets. Legislation reforms that began in 2013 declare Mexico's intent to increase its clean energy generation and expand the opportunities for private investments across the industrial and commercial sectors, attracting financial investments in Mexico's oil, gas, and electricity sectors. These reforms open market opportunities for the cogeneration of heat and power (also called combined heat and power, or CHP) by including efficient CHP under clean electricity generation provisions, qualifying energy projects for benefits such as Clean Energy Certificates $(\mathrm{CEL})^{1}$ and facilitating investment and competition in natural gas, the primary source of CHP (Mordor Intelligence 2017), reducing the price of gas, and increasing the competitive advantage of CHP.

\subsubsection{Oil and Natural Gas Sector Reform}

Before the energy sector reforms, PEMEX had the monopoly to explore, produce, transport, distribute, and commercialize oil and gas in Mexico. Reforms beginning in the early 1990s enabled PEMEX to increase investment through tax regime reductions in certain areas, gradually integrating some upstream competition through restructured exploration, development, and a production service contract. However, PEMEX's lack of resources led to short supplies and overpricing (Robles 2016).

Recent reforms have attracted outside investment into exploration, production, and other activities in the gas sector. Private companies are now able to invest in infrastructure connecting Mexico's upstream and downstream operations to regions previously without access. Investments will also enable the building of additional pipelines from the United States, expanding Mexico's access to large reserves of lower cost natural gas (Vietor and Sheldahl-Thomason 2017).

As part of the reforms, PEMEX transferred all its natural gas pipelines to a new government entity called the National Natural Gas Control Center (CENAGAS). PEMEX remains state owned but has more budgetary and administrative autonomy. Additionally, it is required to compete for bids with other firms on new projects. There is a growing demand for investment in new pipeline capacity to handle planned increases in domestic production, additional imports from the United States, and expansion of access to areas currently without gas. The private sector is already investing in Mexico's midstream and downstream activities, mainly attracted by the growing demand (Dyer 2017).

Private sector investment in the natural gas infrastructure will expand access to natural gas and reduce prices. The price reduction comes first through increased imports of lower cost U.S. gas and, over time, through enhanced development of conventional and shale resources in Mexico. Since natural gas is a preferred fuel for CHP in many applications, both increased access to gas and lower prices should advance CHP development in Mexico.

\footnotetext{
${ }^{1}$ Clean Energy Certificates (CELs) are a policy tool implemented to help Mexico achieve its renewable energy goal: $35 \%$ by 2024. Energy Regulatory Commission (CRE) will issue certificates to new clean energy generation projects, including efficiency cogeneration, based on the amount of clean energy produced. Electricity users must obtain an increasing number of CELs, relative to the electricity consumption, or face fines for noncompliance. CEL requirements and generation are further outlined in Section 3.2.
} 


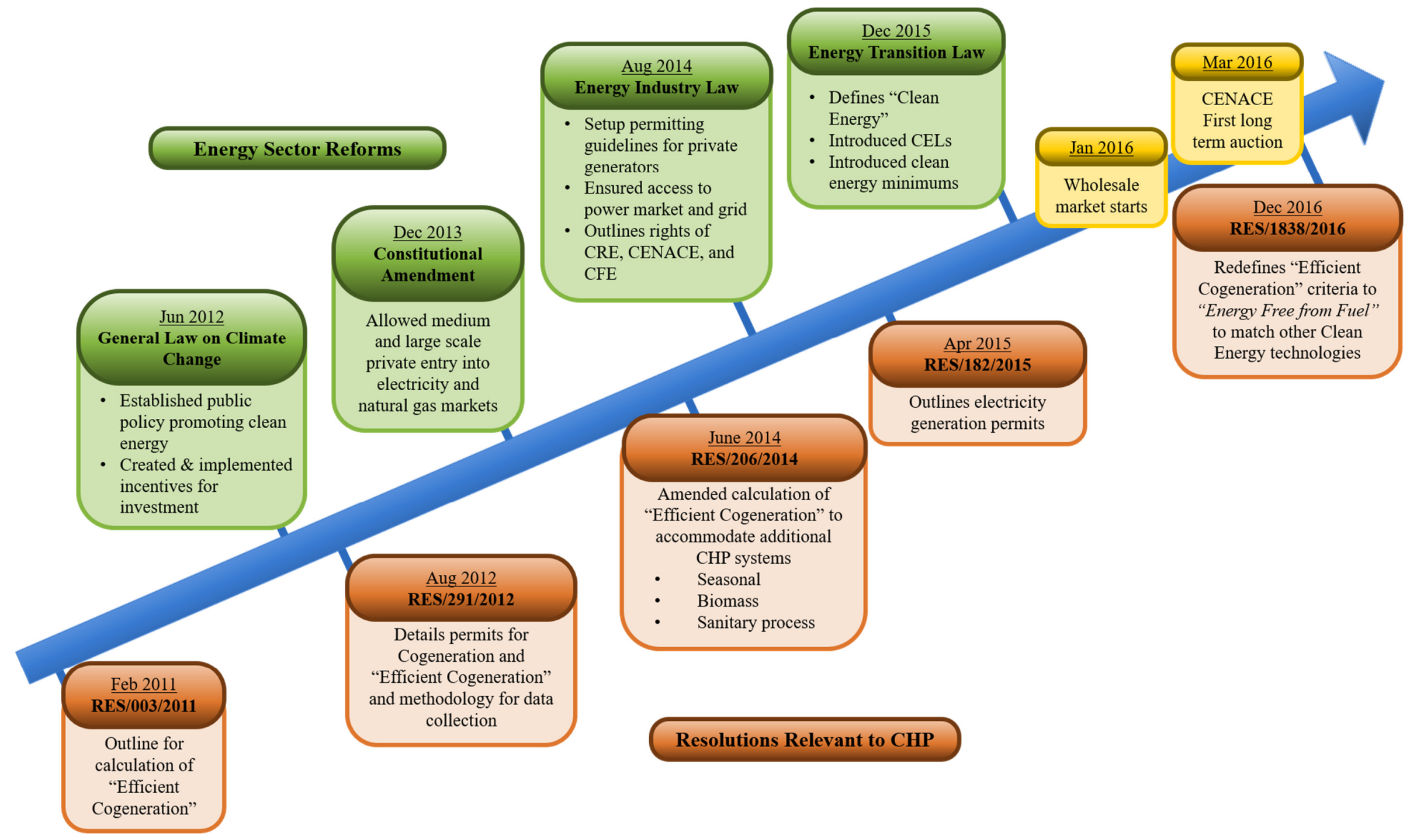

Figure 1. Energy reforms timeline. 


\subsubsection{Electricity Sector Reform}

The legal framework for the Mexican electric sector is set out in the Mexican Constitution Articles 27 and 28 and the Public Electricity Utility Law (Ley del Servicio Público de Energía Eléctrica). Originally, this framework gave the monopoly for the National Electricity System (SEN) to the Federal Electricity Commission (CFE) and the Luz y Fuerza del Centro (LFC), which managed the transmission and distribution (T\&D) of electricity in the Mexico City metropolitan area until 2009. Prior to 1992, CFE and LFC controlled nearly all electricity generation, transmission, distribution, and marketing activities, except for generation for self-use. In December 1992, the government initiated changes to permit entry of private participants in electric power generation, allowing self-generation and the ability to sell excess electricity to CFE (Vietor and Sheldahl-Thomason 2017). These reforms also allowed Independent Power Producers (IPPs) to begin large-scale electricity generation, but they were required to sell to CFE via a bidding process.

Electricity sector reform was an essential step in rehabilitating Mexico's inefficient and expensive utility system serving the country's growing power demand. CFE's budgetary, regulatory, and project-execution limitations prevented new-generation and renewable capacities from keeping pace with the growing demand. Continuing constraints on the T\&D system have also served as a major obstacle to new power generation in several regions. The reforms have created a single free market for power generation and removed the regulatory rigidity of the previous system. The General Law on Climate Change (Ley General de Cambio Climático), signed on June 5, 2012, by President Felipe Calderon, established a public policy supporting the promotion of clean energy (including efficient cogeneration) by creating and implementing incentives for investment (public and private) in renewable sources and efficient cogeneration technologies with the goal of reducing greenhouse gas (GHG) emissions.

A constitutional amendment, ratified in December 2013, established the legal framework for private participation in the energy sector. This was further expanded with the Ley de la Industria Eléctrica or Electric Industry Law (LIE), passed in August 2014, ensuring open access to the power market and grid, and the formation of the Centro Nacional de Control de Energía (CENACE) to handle energy dispatch in the market based on minimizing cost and guaranteeing open access to the national grid. More information on these and other regulatory agencies affected by the reforms can be found in Section 1.2. Overall, these reforms stipulate that private sector generation will now be possible for all types and sizes of projects, including opening the right to invest in the T\&D network, in the hopes that private entities will help expand and modernize the grid.

The government has also begun holding auctions for medium - and long-term ( 3 and 15-year contracts, respectively) power and capacity contracts. Some auctions (i.e., "Energy Auctions") are only available to clean energy projects, which includes efficient cogeneration. When the first and second public offerings for private energy generation were made, the winning bids were solely solar and wind (Vietor and Sheldahl-Thomason 2017).

The Ley de Transición Energética or Energy Transition Law (LTE), passed in December 2015, outlines a framework for regulating the sustainable use of energy, setting the definition and requirements of clean energy, and reducing greenhouse gas (GHG) emissions from the electricity sector (Congreso de la Unión 2015). It sets specific goals for the minimum percentage of clean electricity generation and consumption, sets new energy efficiency requirements on product manufacturers, and introduces the CEL policy. Specific permitting and regulatory frameworks were defined in secondary legislation (Section 1.3).

The governmental push for cleaner electricity production (via energy portfolio goals and CEL requirements) promotes the adoption of efficient CHP through clean energy generation benefits (e.g., 
generates CELs). The reforms also help CHP installations sell any excess generation to CFE, participate in the new energy market, or sell directly to qualified users. ${ }^{2}$

\subsubsection{Other Reforms and Regulations Impacting CHP}

There are also regulations and policies specifically targeting CHP. The Mexican government has published guidance documents to help assess the benefits of CHP and accelerate its deployment: the Methodology to Calculate the Energy Efficiency in Cogeneration Units (Comisión Reguladora de Energía 2011, RES/003/2011) and the General Guidelines for the Accreditation of Cogeneration Units as Efficient Cogeneration (Comisión Reguladora de Energía 2012, RES/291/2012). The efficiency calculation methodology has been further amended (Comisión Reguladora de Energía 2014), RES/206/2014) to include modifications for bio-feedstocks, seasonal systems, and systems associated with sanitary processes (see Section 1.3 for more information on obtaining efficient accreditation).

Beyond direct reforms to the electricity, natural gas, and CHP sectors, there have been other reforms that will positively impact CHP installation (Martínez 2015):

- reform of the Foreign Investment Act to reduce entry barriers to foreign companies,

- reform of the tax regime to incentivize oil and gas investments,

- reform of the Public Administration Act to provide regulatory bodies with independent status, and

- implementation of a carbon tax on fossils fuels (which excludes CHP's most common fuel, natural gas) of about US $\$ 3.5 / \mathrm{tCO}_{2 \mathrm{e}}$.

These reforms are intended to increase government transparency, reduce corruption, increase foreign investment, and promote cleaner energy sources, all of which can help increase CHP utilization in Mexico.

\subsection{OVERVIEW OF THE REGULATORY STRUCTURE ASSOCIATED WITH CHP}

The recent reforms to the electrical and natural gas sectors have also changed the key regulatory authorities governing cogeneration in Mexico and their responsibilities. Figure 2 outlines several key energy-related agencies, while Figure 3 illustrates how they operate and relate to energy retail and CHP installations.
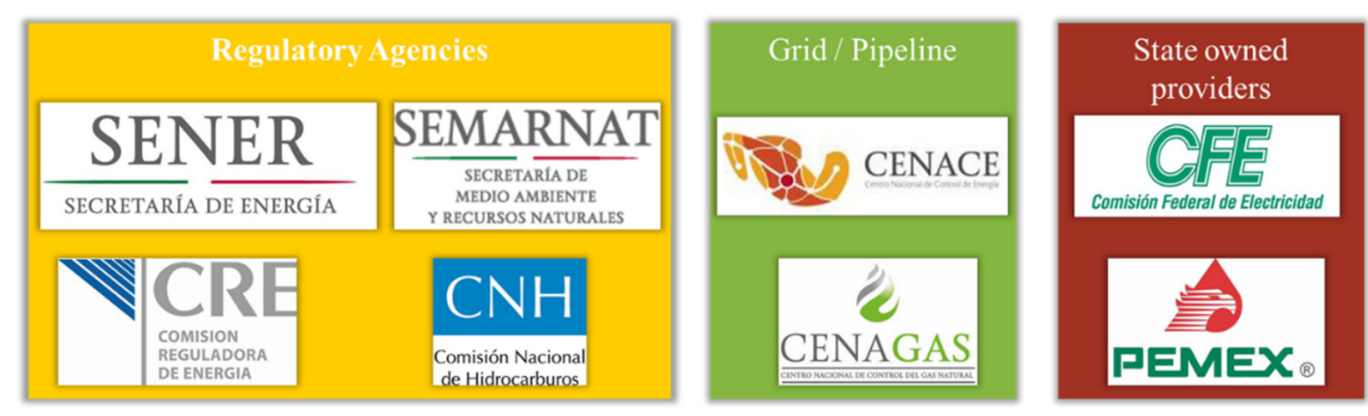

Figure 2. Governmental bodies of the Mexican energy sector.

\footnotetext{
2 "Qualified Users" are commercial or industrial consumers with a peak demand greater or equal to 1 MW and are registered with the CRE.
} 
- $\quad$ SENER - Secretaría de Energía (Secretary of Energy) - is the federal energy agency responsible for national energy policy, including energy efficiency, with authority over private bidding of oil and gas fields.

- SEMARNAT - Secretaría de Medio Ambiente y Recursos Naturales (Secretary of Environment and Natural Resources) - is the federal agency that regulates and supervises the environmental impact of the hydrocarbons sector and new electricity generation, transmission, and distribution projects.

- CONUEE - Comisión Nacional para el Uso Eficiente de la Energía (National Commission for Efficient Energy Use) - is a decentralized independent agency of the SENER that promotes energy efficiency and sustainable energy use. CONUEE seeks to promote CHP in industrial applications. Its mission is to promote energy efficiency and become a technical body on Achievement of Sustainable Energy.

- $\quad$ CNH - Comisión Nacional de Hidrocarburos (National Hydrocarbons Commission) - is independent of SENER and is the upstream regulator and supervises the exploration and extraction of hydrocarbons, in beds or reservoirs, regardless of physical state, including processing activities, transportation, and storage directly related to hydrocarbon exploration and production projects. It is also responsible for conducting national bids and awarding oil and gas contracts.

- $\quad$ CRE - Comisión Reguladora de Energía (Energy Regulatory Commission) - is independent of SENER, with responsibility for regulating the gas (refined, derived from oil and natural gas) and electric power industries. The CRE regulates and issues permits for the generation, transmission, and distribution of electricity and the storage, transportation, and distribution of gas and oil. It also creates fixed porter rates for $\mathrm{T} \& \mathrm{D}$, regulates interconnection criteria and the wholesale electricity market, issues CELs, and issues and regulates the rates of basic electricity supply.

- $\quad$ CENACE - Centro Nacional de Control de Energía (National Center for Energy Control) - is a decentralized agency responsible for providing open access to the T\&D grids of the National Electricity System or Sistema Eléctrico Nacional (SEN) independently of the CFE. This includes administering wholesale (Spot) market, the electricity generation auctions (Bids), and, generally, the purchase and sale market of electricity and guaranteeing the reliability of the SEN (Martínez 2016). CENACE is also responsible for the load dispatching of units connected to the SEN and for the operation of the transmission system from 69 to $400 \mathrm{kV}$.

- CENAGAS - Centro Nacional de Control de Gas Natural (National Center of Control of Natural Gas) - is a decentralized agency responsible for managing the long-term operations of transport and storage within the national pipelines system (taking control from PEMEX).

- $\quad$ CFE - Comisión Federal de Electricidad (The Federal Electricity Commission) - is the state-owned supplier of electricity [controls over $84 \%$ of generating capacity, including third-party owned generators operating under long-term contracts with CFE (Secretaría de Energía de México 2016c)] and the original developer and operator of most of the T\&D system.

- PEMEX - Petróleos Mexicanos (Mexican Petroleum) - is the state-owned supplier of oil and natural gas. 


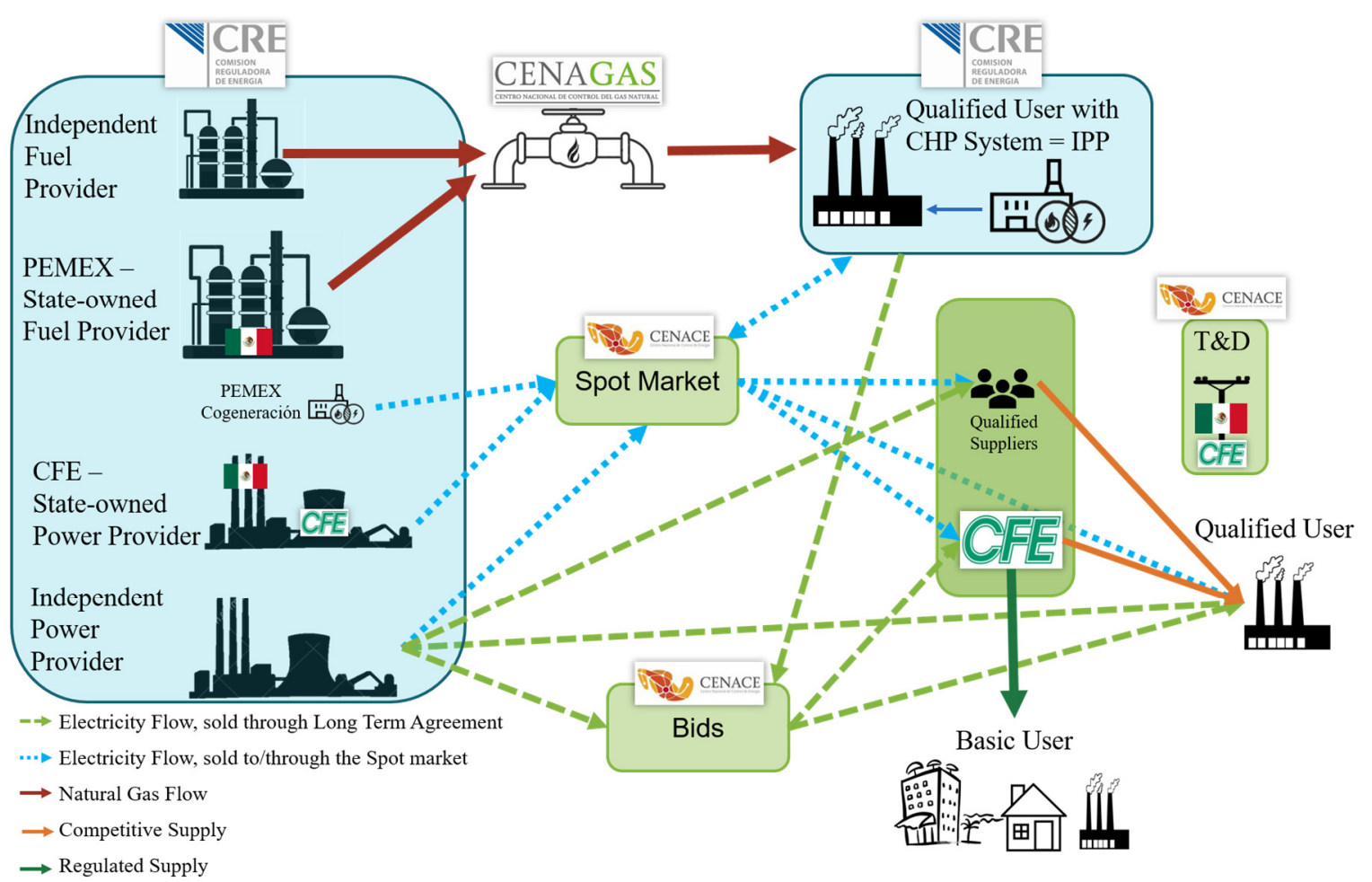

Figure 3. Regulatory bodies and energy flows [adopted from Martínez (2016)].

While not a government institution, Cogenera México, an independent nonprofit trade organization, is dedicated to improving the framework for cogeneration and interacting with interested groups and organizations from the industrial, academic, financial, and public sectors. They hold seminars and workshops promoting and disseminating information about cogeneration in Mexico and provide connections between their partners - other developers, investors, and operators of cogeneration (Cogenera México 2012).

\subsection{MEXICAN COGENERATION PERMITTING}

While recent reforms allow private entities entry into the realm of power generation, it is not as simple as buying a generator. Based on the estimated generation capacity, there are permitting requirements, impact studies (social and environmental), and interconnection contracts to consider (Figure 4). 


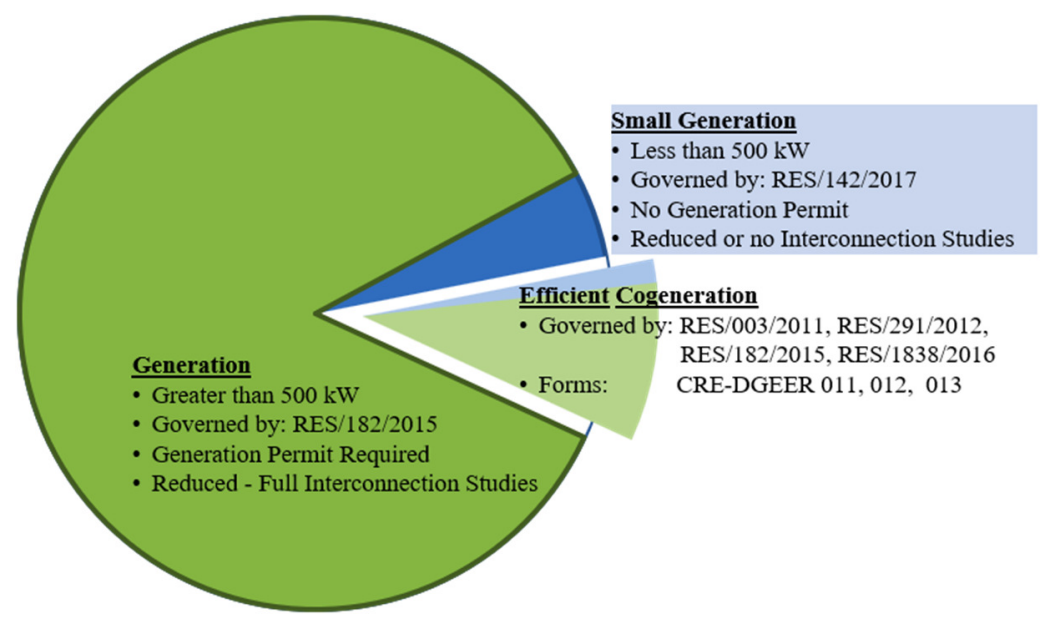

Figure 4. Permitting differences (pie chart not to scale).

\subsubsection{Small Generation (less than $500 \mathrm{~kW}$ )}

The regulatory burden is reduced if the intended generation is less than $500 \mathrm{~kW}$ and clean (i.e., renewables or efficient cogeneration). Distributed generation, outlined in RES/142/2017 (Comisión Reguladora de Energía 2017a), only requires an interconnection contract if intending to connect to the grid.

\subsubsection{Large Generation (500 $\mathrm{kW}$ or larger)}

Larger generation (500 kW or larger), governed by RES/182/2015 (Comisión Reguladora de Energía 2015a), requires an online application and additional documentation. While the permit itself is short (see Table B.1 and Table B.2 in Appendix B), the additional documentation requires

- a general project description,

- proof of the applicant's financial and technical capability to construct the plant and provide electricity,

- a Social Impact Assessment (application or results),

- a business plan, and

- proof of payment for the permit.

Additionally, the application may require municipal permits, forms, and further studies.

Larger generation facilities also require Interconnection Contracts, examples of which can be found in RES/949/2015 (Comisión Reguladora de Energía 2015b).

\subsubsection{Interconnection Studies and Contracts}

For facilities connected to the national grid, the permitting process requires an interconnection contract for both small and large generation. Additionally, before finalizing a contract, several interconnection studies must be conducted to ensure feasibility, determine the impact of the facility on the grid, and what must be done to minimize negative impacts, as well as determine the cost of completing the interconnection. For small facilities, interconnection studies may not be required, but if the studies are deemed necessary, and the facility qualifies as a clean energy resource, there may be no cost to the applicant. 
Details for the interconnection of small-capacity generation can be found in the Manual of Interconnection of Power Generation Centers with a Capacity less than $0.5 \mathrm{MW}$ (Acuerdo por el que se emite el Manual de Interconexión de Centrales de Generación con Capacidad menor a 0.5 MW) (Secretaría de Gobernación 2016). A model contract for facilities this size is detailed in RES/142/2017 (Comisión Reguladora de Energía 2017a).

Table 1. Cost in USD (1 Peso $=0.05336$ USD, 03-06-2018, ${ }^{a}$ not including VAT $)$ and total working days to carry out studies and deliver reports. ${ }^{b}$

\begin{tabular}{|c|c|c|c|c|c|c|}
\hline \multirow{2}{*}{\multicolumn{2}{|c|}{$\begin{array}{c}\text { Capacity } \\
\text { range (MW) }\end{array}$}} & \multicolumn{2}{|c|}{ Interconnection Studies } & \multirow{3}{*}{$\begin{array}{c}\text { Facility Study } \\
\begin{array}{c}\text { Requirements } \\
\text { for network } \\
\text { reinforcement }\end{array} \\
\$ 23,800(25)\end{array}$} & \multirow{3}{*}{$\begin{array}{c}\begin{array}{c}\text { Total for the } \\
\text { project }\end{array} \\
\$ 42,840(45)\end{array}$} & \multirow{3}{*}{$\begin{array}{l}\text { Cost per MW } \\
\$ 4,300-\$ 85,700 \\
\end{array}$} \\
\hline & & Indicative Study & $\begin{array}{l}\text { Impact on the } \\
\text { System Study }\end{array}$ & & & \\
\hline 0.5 & 10 & \multicolumn{2}{|c|}{$\$ 19,040(20)$} & & & \\
\hline 10 & 30 & $\$ 9,520(10)$ & $\$ 19,040(20)$ & $\$ 23,800(25)$ & $\$ 52,360(55)$ & $\$ 1,750-5,240$ \\
\hline 30 & 100 & $\$ 9,520(10)$ & $\$ 28,560(30)$ & $\$ 28,560(30)$ & $\$ 66,640(70)$ & $\$ 670-\$ 2,220$ \\
\hline 100 & 150 & $\$ 14,280(15)$ & $\$ 33,320(35)$ & $\$ 28,560(30)$ & $\$ 76,160(80)$ & $\$ 510-\$ 760$ \\
\hline 150 & 250 & $\$ 19,040(20)$ & $\$ 38,080(40)$ & $\$ 33,320(35)$ & $\$ 90,440(95)$ & $\$ 360-\$ 600$ \\
\hline 250 & 500 & $\$ 23,800(25)$ & $\$ 42,840(45)$ & $\$ 33,320(35)$ & $\$ 99,960(105)$ & $\$ 200-\$ 400$ \\
\hline 500 & 750 & $\$ 28,560(30)$ & $\$ 47,600(50)$ & $\$ 38,080(40)$ & $\$ 114,240(120)$ & $\$ 150-\$ 230$ \\
\hline 750 & 1000 & $\$ 38,080(40)$ & $\$ 57,120(60)$ & $\$ 38,080(40)$ & $\$ 133,280(140)$ & $\$ 130-\$ 180$ \\
\hline 1000 & -- & $\$ 47,600(50)$ & $\$ 66,640(70)$ & $\$ 38,080(40)$ & $\$ 152,320(160)$ & $<\$ 150$ \\
\hline
\end{tabular}

$a$ "The Money Converter" (2018)

${ }^{b}$ Centro Nacional de Control de Energía (2015)

In general, for facilities generating more than $10 \mathrm{MW}$, three interconnection studies are required, which can be processed online (Table 1). The costs for the interconnection studies are set by CENACE in pesos (Centro Nacional de Control de Energía 2015); a conversion of 0.05336 USD per peso was used, based on the conversion rate on March 6, 2018("The Money Converter" 2018). Details on what is required for each study can be found in Criteria for Interconnection of Power Plants and Connection of Loading Centers (Criterios mediante los que se establecen las características especificas de la infraestructura requerida para la Interconexión de Centrales Eléctricas y Conexión de Centros de Carga) (Centro Nacional de Control de Energía 2015). The first study assesses the feasibility of the project, so the applicant can evaluate if they want to continue with the process. After CENACE approves the first study and the response is received, the applicant has 10 working days to request the next study. The next study determines what work is necessary to complete the interconnection and model the necessary reinforcements to the grid, to ensure reliability. Again, the applicant has 10 working days to request the final study, which characterizes the costs of completing the interconnection and reinforcements to the grid. Upon completion, the applicant must submit those studies, as well as some additional documentation, to request an Interconnection Contract (see Table B.3 in Appendix B). The additional documentation includes

- a Letter of Commitment to (or contract for) the construction of project,

- a detailed work plan for construction,

- documentation of control of the project property, and

- proof of payment for the Interconnection Studies.

For medium-sized facilities ( $500 \mathrm{~kW}-10 \mathrm{MW}$ ), some of the studies may be simplified and combined, allowing a quicker and less expensive application process. While these studies are necessary for installations greater than $500 \mathrm{~kW}$, the high cost per MW and technical requirements can be a deterrent for 
smaller power systems (Table 1). Model contracts for facilities greater than $500 \mathrm{~kW}$ are detailed in RES/949/2015 (Comisión Reguladora de Energía 2015b).

\subsubsection{Efficient Cogeneration}

In Mexico, cogeneration systems can be eligible for classification as a clean energy, giving the permit holder the ability to generate CELs. If applying efficient accreditation before installation is complete, some of the permitting procedures (e.g., interconnection studies) may be simplified or cost less. There may also be funds available to help with financing (LTE, Title 4, Articles 43-67) (Congreso de la Unión 2015) and accelerated depreciation of the cogeneration equipment during the first year of operation.

The application process for efficient generation is outlined in RES/291/2012 (Comisión Reguladora de Energía 2012), which describes the forms required and the information needed for the classification (e.g., relevant parameters needed, how to measure them, accreditation of the measurer, testing). Applying for accreditation requires three forms: an application for accreditation, an application to authorize a measurer, and a technical report, issued by the measurer (outlined in Table 2 and further detailed in Tables B.4, B.5, and B.6 in Appendix B).

Table 2. Forms required to obtain Efficient Accreditation. ${ }^{a}$

\begin{tabular}{cl}
\hline Form number & \multicolumn{1}{c}{ Form name } \\
\hline CRE-DGEER-011 & Application to obtain accreditation as efficient cogeneration \\
CRE-DGEER-012 & Application for authorization for people measuring the variables in cogeneration system \\
CRE-DGEER-013 & Technical report of the parameter-input survey for calculations \\
\hline
\end{tabular}

${ }^{a}$ Comisión Reguladora de Energía (2012)

Generation permit holders can apply for this accreditation before operation begins but must prove that the system is efficient within six months of startup or the interconnection contract will be terminated, and the permit holders must reimburse the profits. Accreditation is valid for a length of time depending on the capacity of the cogeneration system (Table 3 ).

Table 3. Length of accreditation for Efficient Accreditation.

\begin{tabular}{cc}
\hline System capacity (MW) & $\begin{array}{c}\text { Length of accreditation } \\
\text { (years) }\end{array}$ \\
\hline$<0.03$ & $\begin{array}{c}\text { Automatically "efficient" } \\
0.03-0.5\end{array}$ \\
$0.5-30$ & 3 \\
$30-100$ & 2 \\
$\geq 100$ & 1 \\
\hline${ }^{a}$ Comisión Reguladora de Energía (2011)
\end{tabular}

The calculations for determining if a cogeneration system is efficient are outlined in RES/003/2011 (Comisión Reguladora de Energía 2011) and amended by RES/206/2014 (Comisión Reguladora de Energía 2014) and RES/1838/2016 (Comisión Reguladora de Energía 2016d). There are three major variables that must be measured by an accredited person:

$E=$ net annual electricity produced by the system, measured at the point of connection of the generators; 
$F=$ net annual total heat generated by the system, based on the lower heating value of the fossil fuel; and

$H=$ net annual useful heat or thermal energy generated by the system and used in a productive process.

The fuel-free energy of the system is determined by the formula

$$
E L C=\left[\frac{E}{R e f E * f p}+\frac{H}{R e f H}-F\right] \cdot \operatorname{RefE},
$$

where

$R e f E=$ a reference value for $E$ (see Table 4),

$R e f H=$ a reference value for $H$ (dependent on type of heating system-either $82 \%$ or $90 \%$ ), and $f p=$ the electrical energy loss factor (see Table 5).

Table 4. Reference values (RefE and $R e f H)$ for calculation of Fuel-free Energy. ${ }^{a}$

\begin{tabular}{ccc}
\hline System capacity (MW) & RefE & RefE (high altitude) \\
\hline$<0.5$ & $40 \%$ & $40 \%$ \\
$0.5-6$ & $44 \%$ & $44 \%$ \\
$6-15$ & $47 \%$ & $45 \%$ \\
$15-30$ & $48 \%$ & $45 \%$ \\
$30-150$ & $51 \%$ & -- \\
$150-300$ & $52 \%$ & --- \\
$\geq 300$ & $53 \%$ & --- \\
\hline \multicolumn{2}{c}{ Type of System } \\
Steam/Hot water for heating medium & RefH \\
Direct use of combustion gases & $80 \%$ \\
\hline${ }^{a}$ Comisión Reguladora de Energía (2016d)
\end{tabular}

Table 5. Reference values $(f p)$ for the calculation of fuel-free energy ${ }^{a}$

\begin{tabular}{cc}
\hline Voltage range $(\mathbf{k V})$ & $\boldsymbol{f p}$ \\
\hline$<1.0$ & 0.91 \\
$1.0-34.5$ & 0.94 \\
$69-85$ & 0.96 \\
$115-230$ & 0.98 \\
$\geq 400$ & 1.0 \\
\hline${ }^{a}$ Comisión Reguladora de Energía (2016d) &
\end{tabular}

The CRE will consider a system to be an efficient cogeneration process if the $E L C$ is greater than zero (Comisión Reguladora de Energía 2016d). In the amended resolution (Comisión Reguladora de Energía 2014, RES/206/2014) there are different calculations to account for common variations in cogeneration systems (e.g., bio-feedstocks, systems that have large variations between seasons, and systems associated with a sanitary process). Additionally, for systems installed at an altitude higher than 1500 meters above sea level, generating with internal combustion engines or gas turbines, the RefE values are adjusted (see Table 4). 
CELs are generated using the percentage of Fuel-free Energy determined by the formula

$$
\% E L C=\frac{E L C}{E} .
$$

The above criterion does not apply to cogeneration systems that use thermal energy not used in the process (waste heat to power) or the fuels generated in the process and that do not require the additional use of fossil fuels. Those systems will have a percentage of fuel-free energy equal to $100 \%$. 


\section{ENERGY AND CHP MARKETS IN MEXICO}

\subsection{CURRENT ENERGY DEMAND}

\subsubsection{Electricity Demand}

Mexico used over 300 TWh of electricity in 2017 (Secretaría de Energía de México 2018), most of which $(60 \%)$ was used by the industrial sector and very little $(8 \%)$ by the commercial sector (Secretaría de Energía de México 2017a). Mexico generated 329 TWh of electricity in 2017; over 50\% was generated by combined cycle plants (Secretaría de Energía de México 2018). Mexico's clean energy generation accounts for $20 \%$ of the country's energy matrix, but recent policies and financial incentives such as CEL requirements, LTE goals, and the outcomes of the first two energy auctions are expected to boost the generation of clean energy in the coming years, to almost $40 \%$ by 2032 (Secretaría de Energía de México 2018). Until 2012, nearly all electricity generation in Mexico came from CFE (major exceptions being self-generation CHP installations). Now, however, $27.8 \%$ of the electricity generated is from private investment (Alvarez et al. 2017). Figure 5 shows actual and predicted energy generation based on various energy-generating technologies.

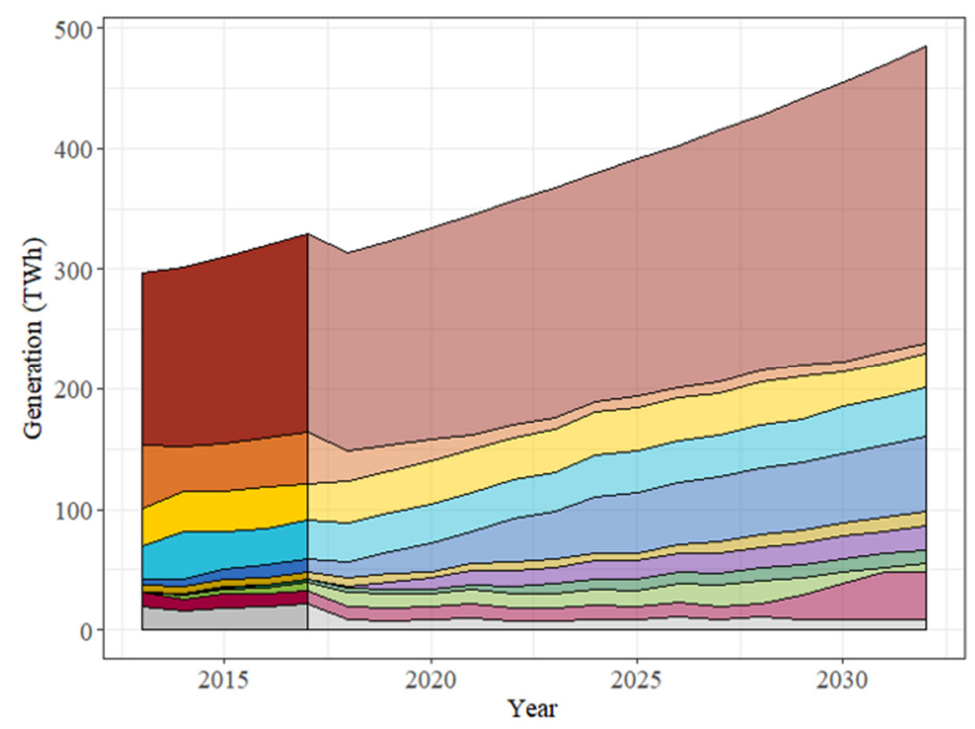

\begin{tabular}{|lrrr}
\hline Combined Cycle & 2013 & 2017 & 2032 \\
\hline \hline Conventional Thermoelectric $17.5 \%$ & $13.0 \%$ & $1.6 \%$ \\
\hline \hline Coal & $10.6 \%$ & $9.3 \%$ & $6.0 \%$ \\
\hline \hline Hydroelectric & $9.4 \%$ & $9.7 \%$ & $8.4 \%$ \\
\hline Wind & $1.4 \%$ & $3.2 \%$ & $12.8 \%$ \\
\hline \hline Geothermal & $2.0 \%$ & $1.8 \%$ & $2.5 \%$ \\
\hline Solar & $0.0 \%$ & $0.1 \%$ & $4.1 \%$ \\
\hline \hline Bioenergy & $0.2 \%$ & $0.6 \%$ & $2.2 \%$ \\
\hline Efficient Cogeneration & $0.0 \%$ & $2.1 \%$ & $1.6 \%$ \\
\hline \hline Nuclear & $4.0 \%$ & $3.3 \%$ & $8.0 \%$ \\
\hline Other & $6.4 \%$ & $6.7 \%$ & $1.9 \%$
\end{tabular}

Figure 5. Actual and predicted generation (TWh) segregated by generation technology (Secretaría de Energía de México 2017c, 2015, 2016b, 2018).

Mexico's total electrical generation capacity is $77.1 \mathrm{GW}$, as of April 2018 (Comisión Reguladora de Energía 2018). Most of this capacity is from natural gas $(43 \%, 33 \mathrm{GW})$ or another fuel in combination with natural gas $(7.8 \%, 6.0 \mathrm{GW})$ (Comisión Reguladora de Energía 2018); however, many generators use a combination of fuels, making it difficult to determine a true breakdown of generation capacity by fuel. Other major fuels include coal, hydroelectric power, and wind (Figure 6). 


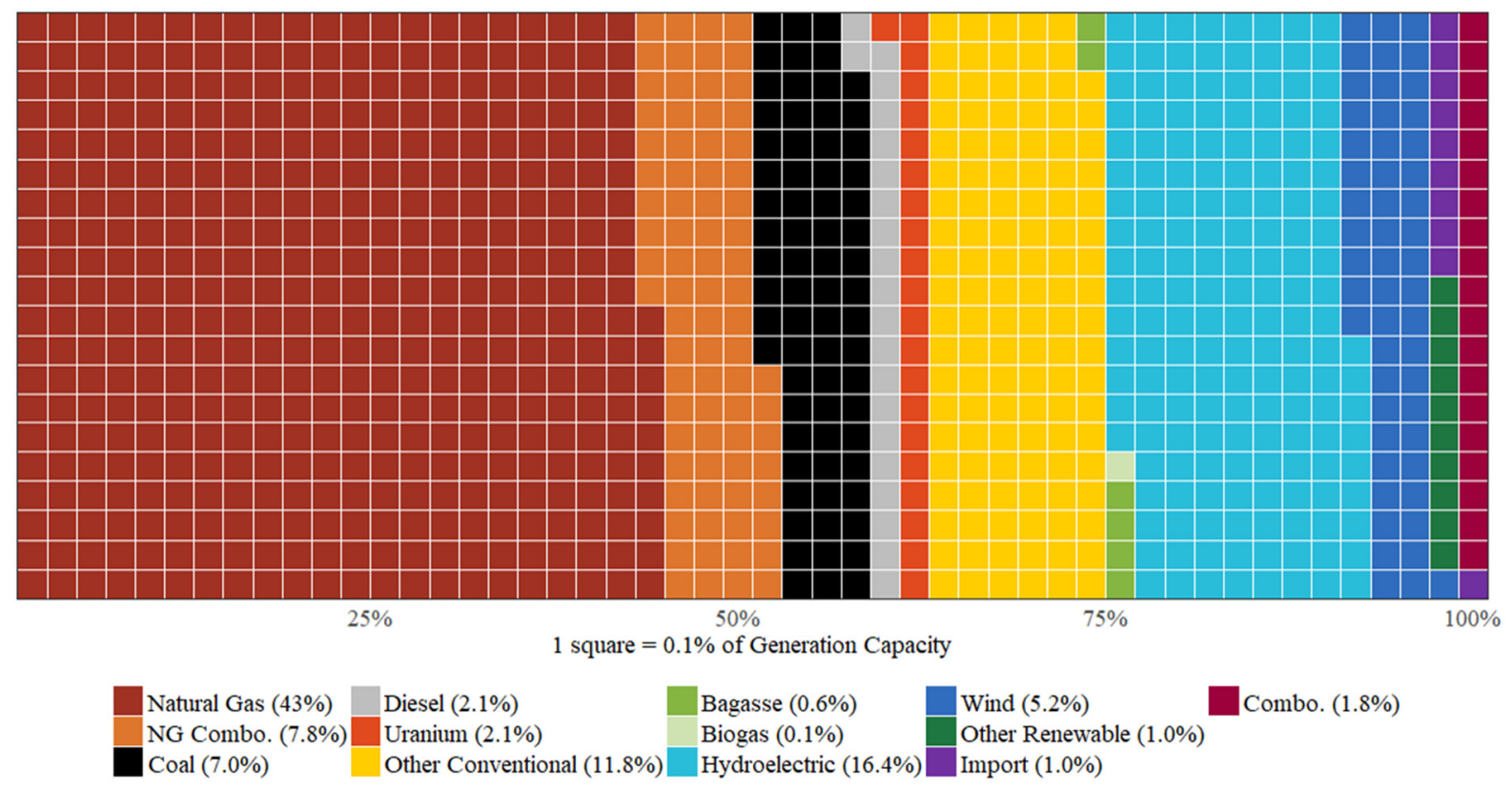

Figure 6. Breakdown of Mexican energy generation capacity by fuel (Comisión Reguladora de Energía 2018).

In addition to the increased demand for cleaner energy, there is a growing demand for electricity (Figure 7). The 2018 Programa de Desarrollo del Sistema Eléctrico Nacional (PRODESEN), the published official energy plan of Mexico, forecasts a 2.6-3.6 \% annual average growth rate for peak demand and $2.5-3.5 \%$ increase in total consumption over the next decade, culminating in an increase of up to nearly 70\% by 2032 (over 2018 estimated consumption) (Secretaría de Energía de México 2017c).

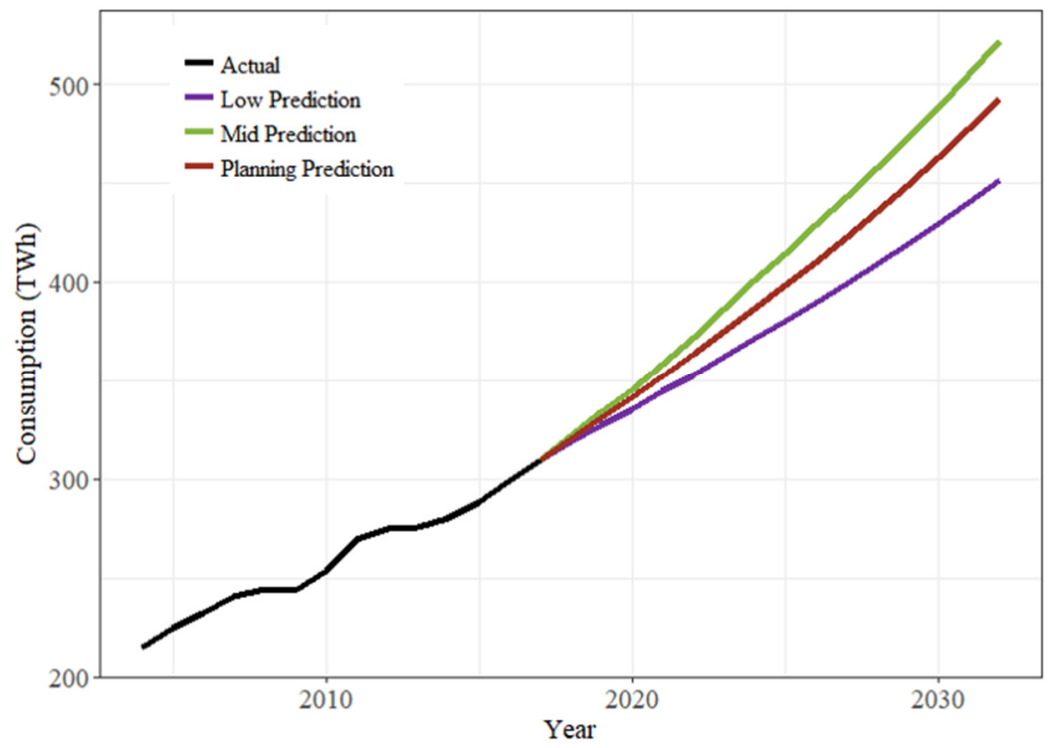

Figure 7. Mexican actual and forecast electricity consumption (Secretaría de Energía de México 2018).

Mexico is also focusing on expanding and modernizing its grid, expecting investments of over US\$15 billion in grid expansion, voltage increases, high-voltage direct current (HVDC) transmission lines, battery bank storage, and smart grid projects between 2018 and 2032 (Secretaría de Energía de México 
2018). In 2016, T\&D losses averaged about $14.7 \%$ (both technical and nontechnical [theft] losses), a reduction of over 3 percentage points from 2013 levels (Alvarez et al. 2017).

\subsubsection{Natural Gas Demand}

As stated above, natural gas is the most common fuel used by electricity producers in Mexico (42-50\%); it is also the most prevalent fuel used for CHP applications. Between 1997 and 2014, the consumption of natural gas in Mexico increased from 4.6 to 8.2 billion cubic feet, with imports growing from 3 to $30 \%$ of the Mexican market (Martínez 2015).

Figure 8 shows the status of natural gas pipelines in Mexico along with new CENAGAS and private pipelines under construction (Centro Nacional de Control del Gas Natural 2016). Grey lines are operating CENAGAS pipelines; red dashed lines represent privately owned, operating pipelines; green lines (solid and dashed) represent planned pipelines; and solid red lines represent "other" pipelines.

Like electricity, recent reforms have opened the natural gas infrastructure to private investment. According to PRODESEN, seven pipeline

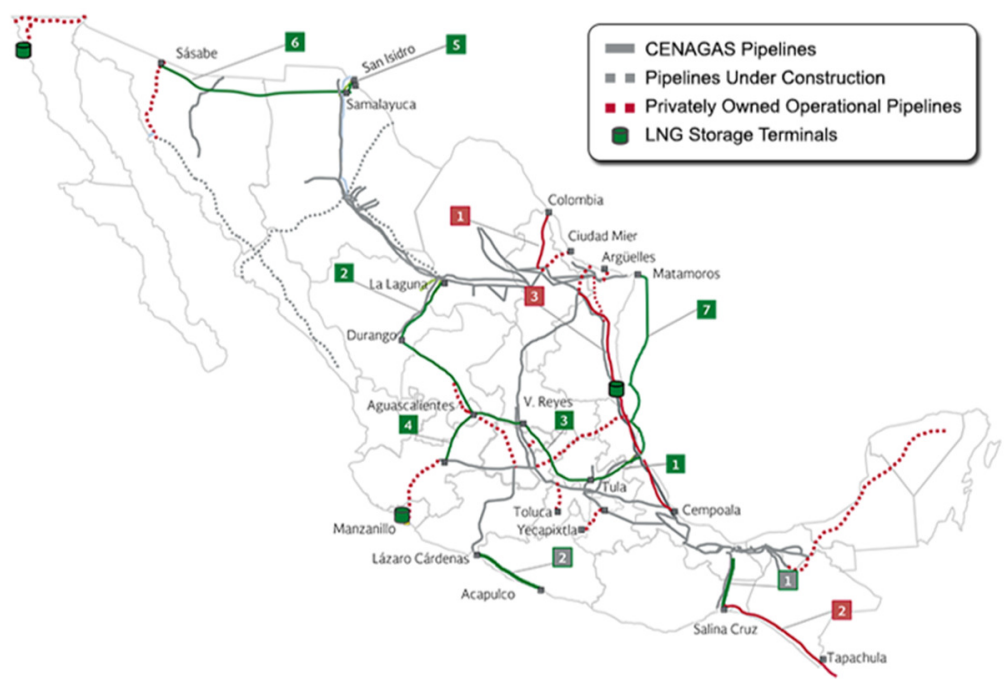

Figure 8. Mexican natural gas actual and planned pipelines (Centro Nacional de Control del Gas Natural 2016). projects were awarded with in service dates of 2017 or 2018, two more projects are out for bid, and three additional projects are under consideration (Alvarez et al. 2017). This will result in an additional 5,200 km of pipelines $(8800 \mathrm{~km}$ already exist) (Vietor and Sheldahl-Thomason 2017) and represent a total investment of US\$8.1 billion (Alvarez et al. 2017).

\subsection{CHP INSTALLED CAPACITY AND APPLICATIONS AND CURRENT MARKET ACTIVITY}

CHP development in Mexico includes a large range of system sizes and technologies. Small to medium sized natural gas engines, microturbines and combustion turbines serve the electricity and thermal energy needs of commercial buildings and industrial facilities, while large combined cycle CHP units provide steam and power to large industrial facilities, such as refineries, in addition to selling excess power into the grid. The total operational CHP capacity was approximately $4.1 \mathrm{GW}$ (5.4\% of Mexico's total electricity generation capacity) as of the end of 2017 (Secretaría de Energía de México 2017c, 2018; Comisión Reguladora de Energía 2018), ${ }^{3}$ up from 3.29 GW in 2013 (Mordor Intelligence 2017). These CHP projects were installed slowly over the past 20 years, CHP being one of the first entries into electricity generation prior to the recent reforms. Efficient cogeneration accounted for none of the

\footnotetext{
${ }^{3}$ Data for cogeneration permits in this section were obtained by cross-referencing data within Secretaría de Energía de Mexico (2017c, 2018) and Comisión Reguladora de Energía (2018) to determine generation permits that were issued to cogeneration units and which units have obtained efficient accreditation. Since CHP units smaller than $500 \mathrm{~kW}$ do not require permit, this report may be underrepresenting this size class.
} 
generation in 2013 but rose to $583 \mathrm{MW}$ by 2015 and doubled to over 1,250 MW in 2018, as established CHP facilities retroactively gained accreditation (Mordor Intelligence 2017). Currently almost 30\% of all CHP permits have efficient accreditation (Figure 9 and Figure 10) (Secretaría de Energía de México 2017c; Comisión Reguladora de Energía 2017b).

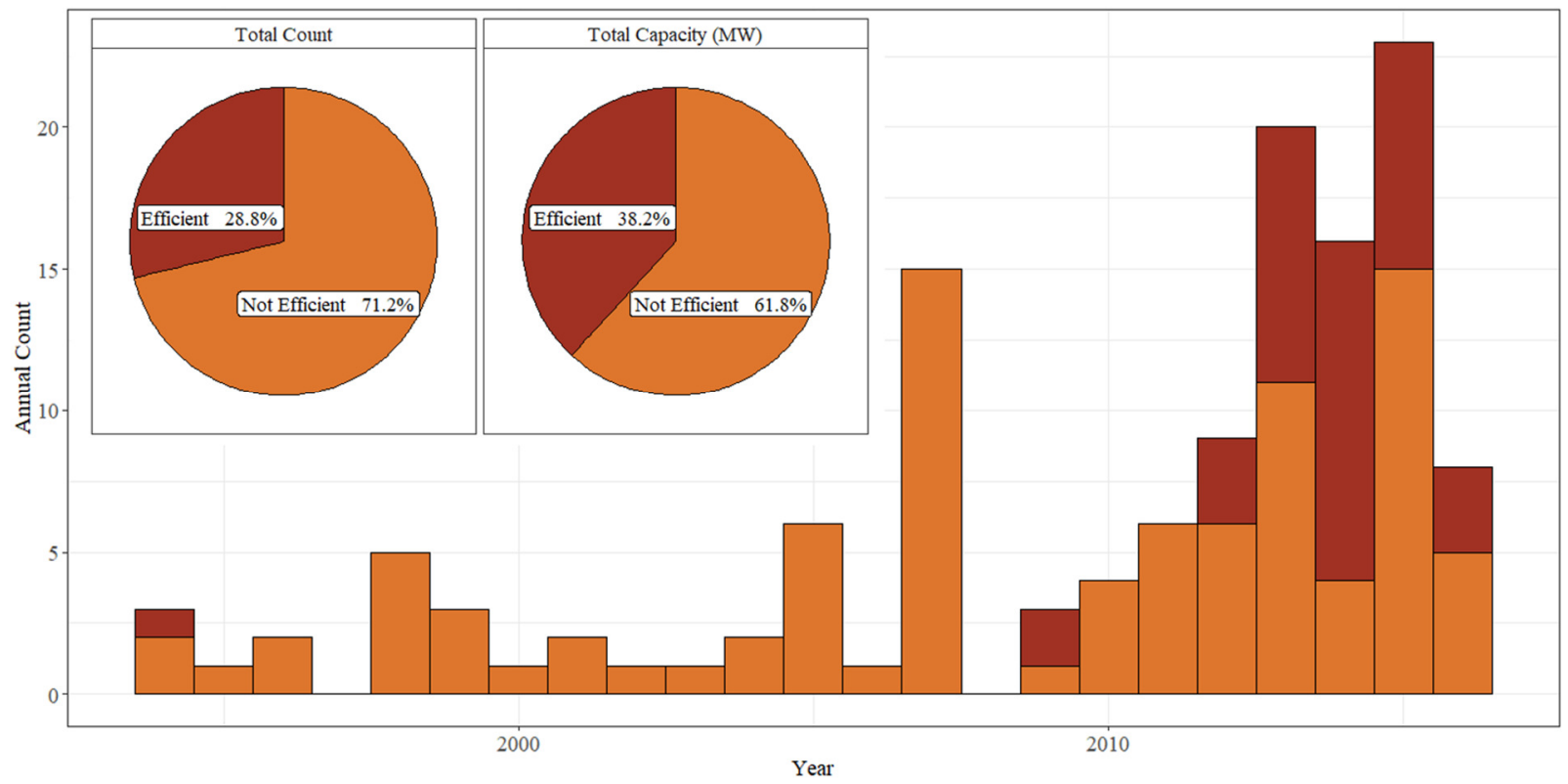

Figure 9. Annual count of cogeneration permits granted and have since been classified as efficient (Secretaría de Energía de México 2017c, 2016a; Comisión Reguladora de Energía 2018).

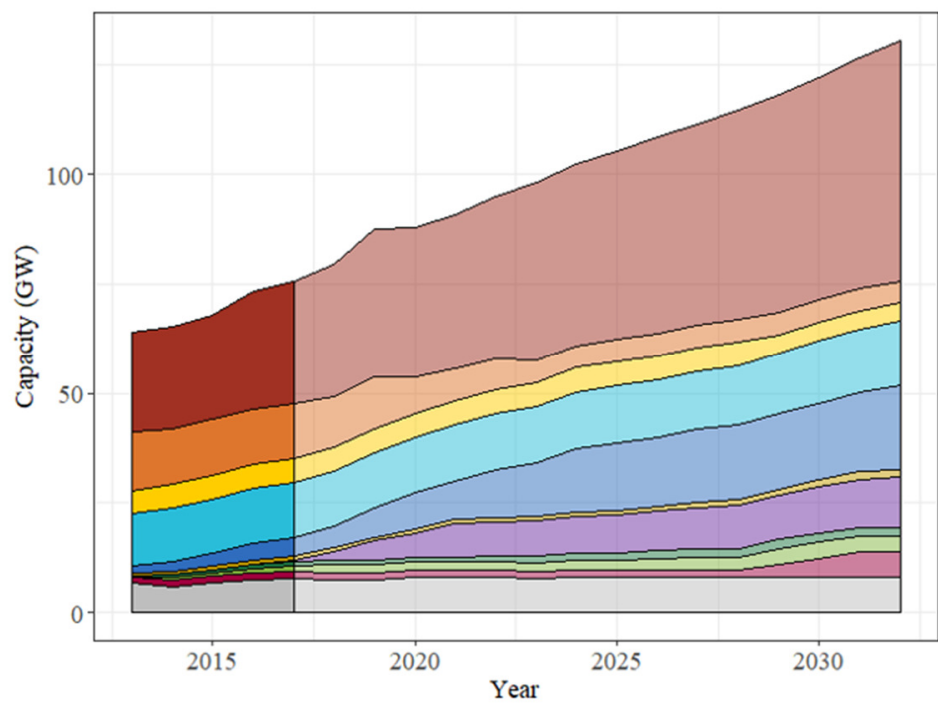

\begin{tabular}{|lrrr}
\hline Combined Cycle & 2013 & 2017 & 2032 \\
\hline Conventional Thermoelectric & $36 \%$ & $37 \%$ & $42 \%$ \\
\hline Coal & $21 \%$ & $17 \%$ & $3.9 \%$ \\
\hline Hydroelectric & $8.4 \%$ & $7.1 \%$ & $3.2 \%$ \\
\hline Wind & $18 \%$ & $17 \%$ & $11 \%$ \\
\hline Geothermal & $2.5 \%$ & $5.5 \%$ & $15 \%$ \\
\hline Solar & $1.3 \%$ & $1.2 \%$ & $1.3 \%$ \\
\hline Bioenergy & $0.1 \%$ & $0.3 \%$ & $8.9 \%$ \\
\hline Efficient Cogeneration & $0.2 \%$ & $1.3 \%$ & $1.5 \%$ \\
\hline Nuclear & $0.0 \%$ & $1.7 \%$ & $2.8 \%$ \\
\hline Other & $2.2 \%$ & $2.1 \%$ & $4.4 \%$ \\
\hline & $10 \%$ & $10 \%$ & $6.2 \%$
\end{tabular}

Figure 10. Actual and predicted capacity (MW) segregated by generation technology (Secretaría de Energía de México 2017c, 2015, 2016b, 2018).

CHP is utilized heavily in the industrial sector, moderately in the commercial sector, and sparingly in the residential sector. Figure 11 illustrates the installed CHP capacity of all three sectors, comparing them to the electricity and energy use average breakdown by sector. It is important to note that Figure 11 underestimates the national average electricity for the commercial sector, as the CRE does not differentiate between commercial and industrial energy users at the medium voltage. Government of 
Mexico experts estimate that the national electricity usage for the commercial sector is approximately $20 \%$, reducing the national electricity use for the industrial sector down to $49 \%{ }^{4}$. The industrial and commercial sectors are broken down further in Figure 12 and Figure 13.

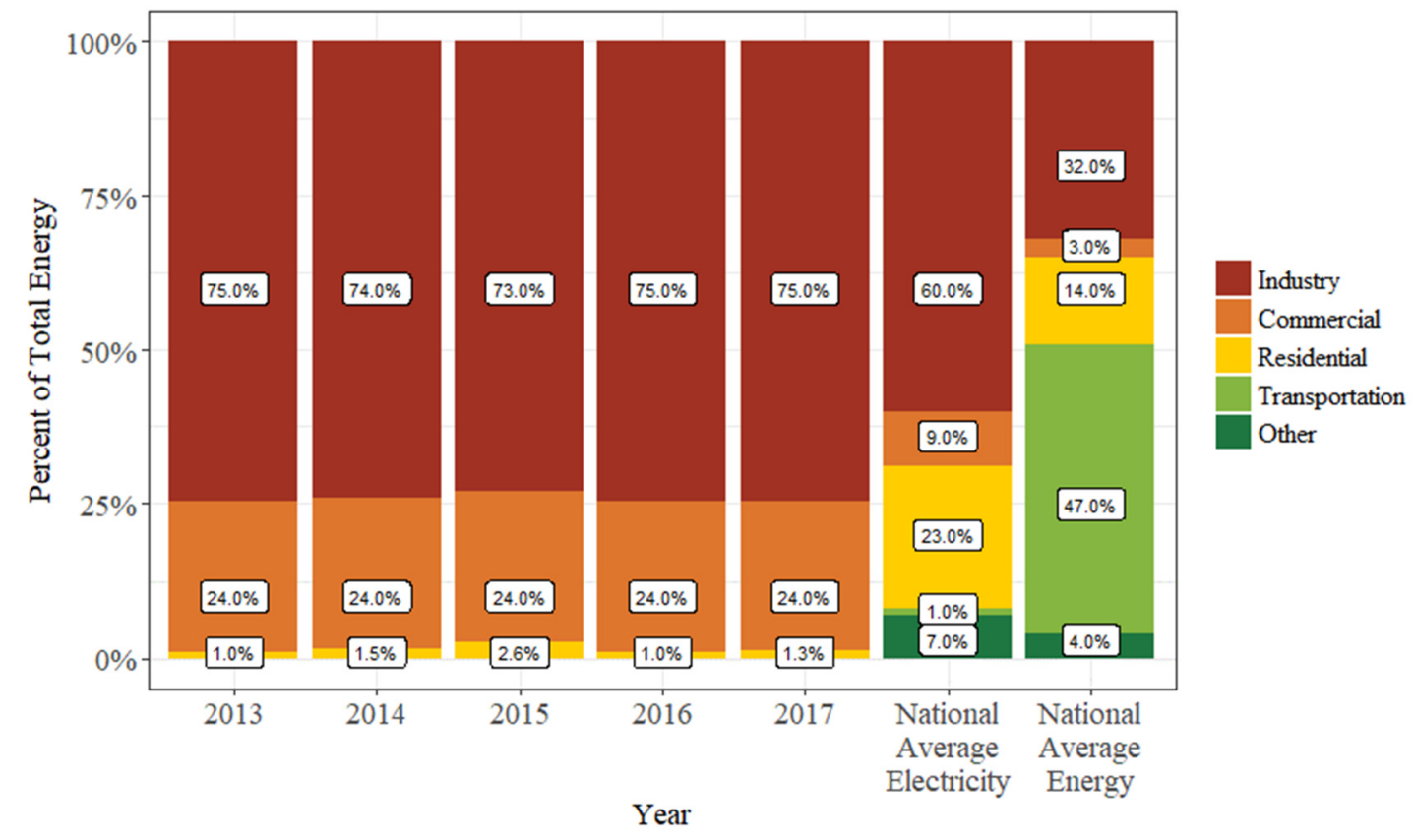

Figure 11. Fraction of CHP capacity (Mordor Intelligence 2017) compared to national electricity (Secretaría de Energía de México 2017a) and energy use (Secretaría de Energía de México 2017b) by end-use sector.

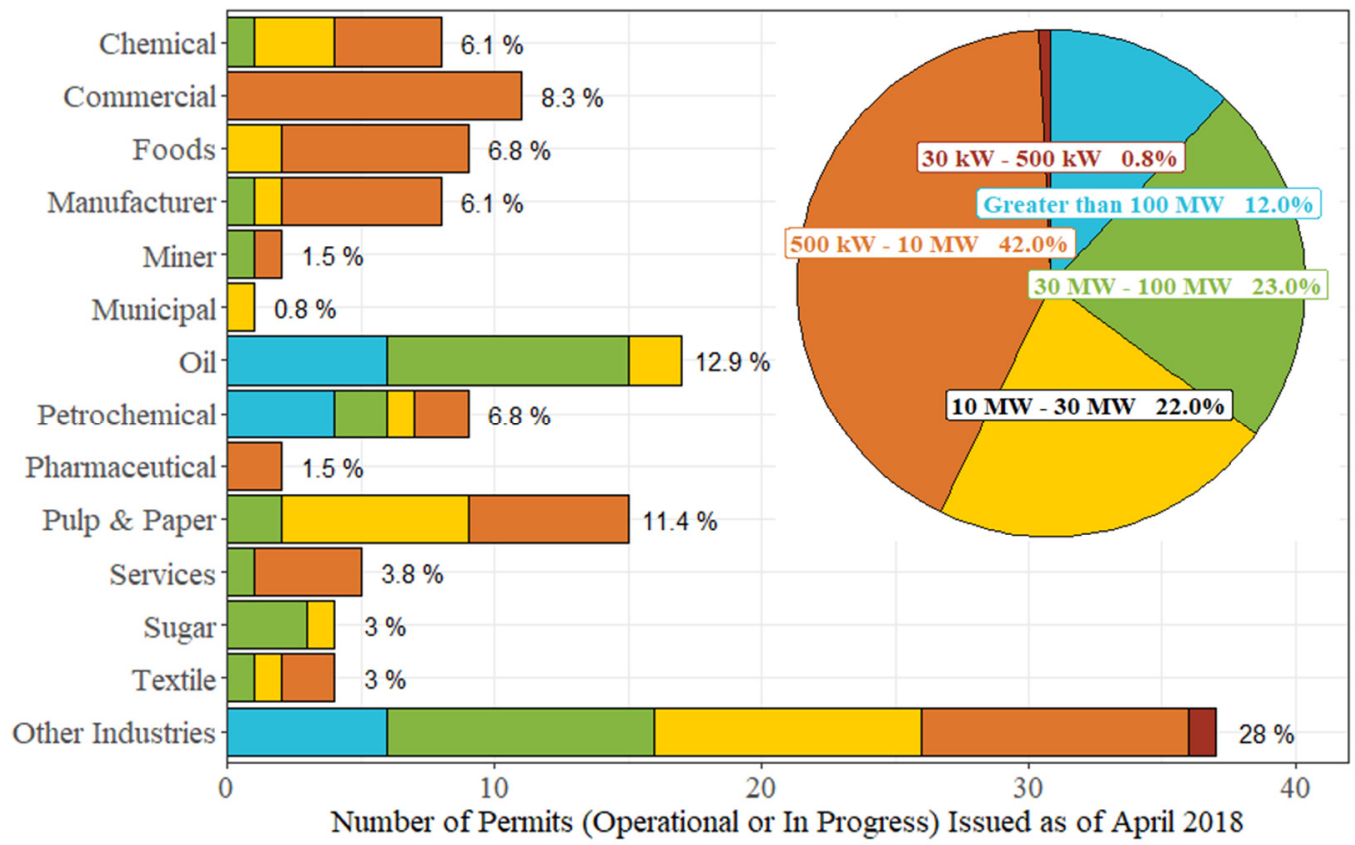

Figure 12. Breakdown of granted permits by size and sector (Secretaría de Energía de México 2017c; Comisión Reguladora de Energía 2017b).

${ }^{4}$ Personal Communication with Israel Jáuregui Nares of CONUEE on 24 July 2018. 
Figure 12 and Figure 13 show the breakdown of existing CHP permits (operating units, plus those under construction and starting work), as of October 2017, by number of permits (Figure 12) and generation capacity (Figure 13), broken down by sector and capacity range (Secretaría de Energía de México 2017c; Comisión Reguladora de Energía 2017b). The oil industry has installed most of the CHP units and capacity (mostly PEMEX), utilizing the heat generated in refining and need for steam. The chemical/ petrochemical, commercial, foods and pulp and paper are other major CHP sectors. The sector "Other Industries" also holds a high number of permits, many of which are likely to be medium voltage commercial facilities.

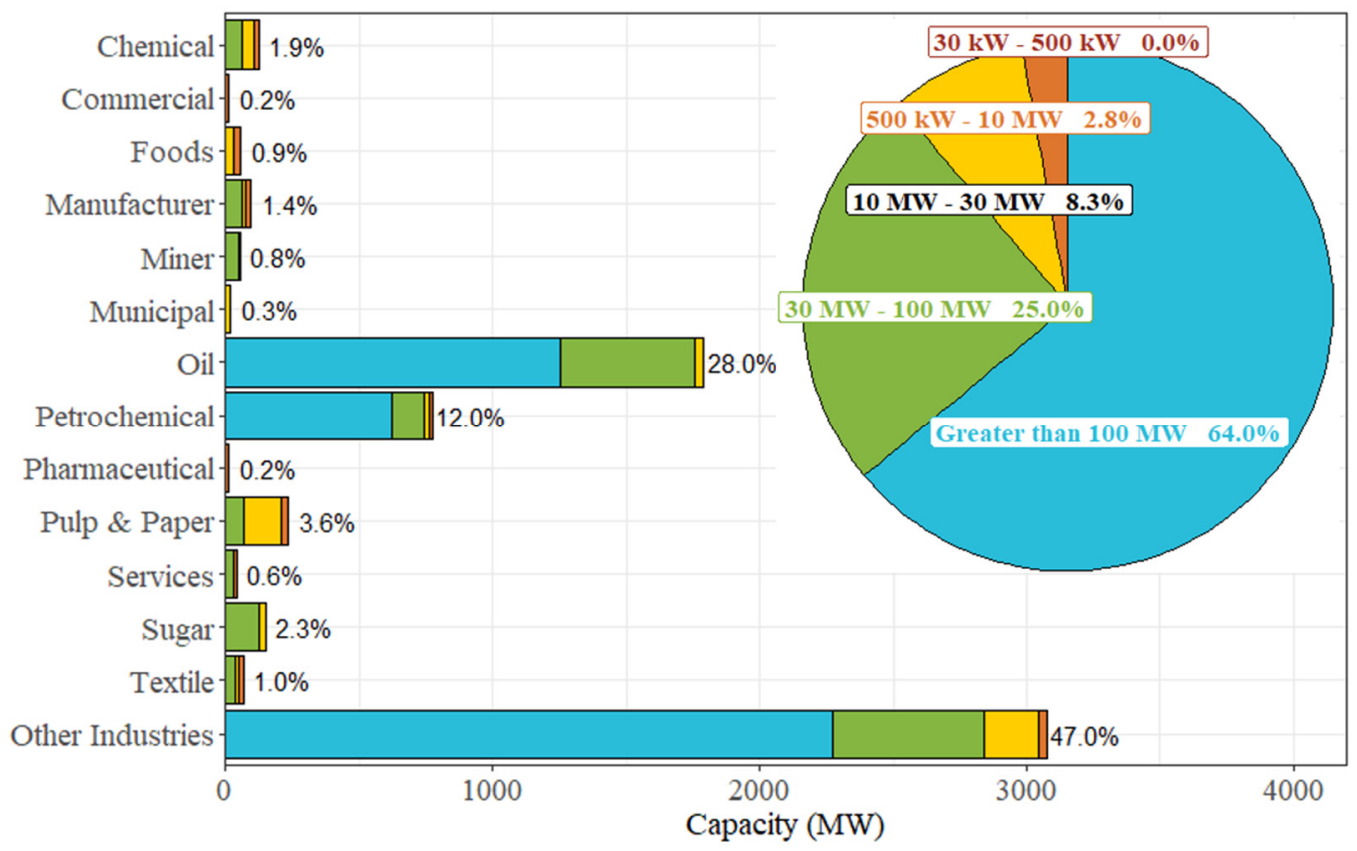

Figure 13. Capacity breakdown of granted permits by size and industrial sector (Secretaría de Energía de México 2017c; Comisión Reguladora de Energía 2016c).

Many CHP units permitted in Mexico are within the medium size range (500 kW-10 MW), taking advantage of the lower interconnect studies requirements, though most are larger than $10 \mathrm{MW}$ (57\% by count). Very few permitted units are smaller than $500 \mathrm{~kW}^{5}$, despite the benefits: units do not require full permits use simpler interconnection contracts, and still generate CELs. This range represents a significant potential area for CHP uptake in commercial and even industrial settings.

In 2016, about three-quarters of the Mexican CHP capacity was captive, connected to the grid but dedicated to their facility and with no capacity available for export to the grid. Industrial CHP at gas refineries, sugar factories and in the paper-pulp industry are often captive as a more technically and financially viable option. Furthermore, by reducing the demand on the grid, large-scale, captive CHP projects help stabilize energy prices and reduce electric grid load. Additionally, off-grid CHP could be a significant opportunity for rural applications such as lighting, vaccine refrigeration, and agricultural and residential water pumping (Mordor Intelligence 2017).

Access to natural gas (or other fuel) is essential to cost-effective CHP projects. Figure 14 shows the geographic distribution of cogeneration permits listed as operational. If compared to Figure 8 , there are

\footnotetext{
${ }^{5}$ This report tracked the CHP facilities by permits recorded. Since CHP units smaller than $500 \mathrm{~kW}$ do not require permit, this report may be underrepresenting this size class.
} 
generally more CHP permits issued where there are prevalent natural gas lines. While the presence of natural gas pipelines in the state is not a full predictor of the presence of cogeneration units, it does illustrate cogenerations reliance on natural gas (see Section 2.1 for more information on natural gas pipelines).

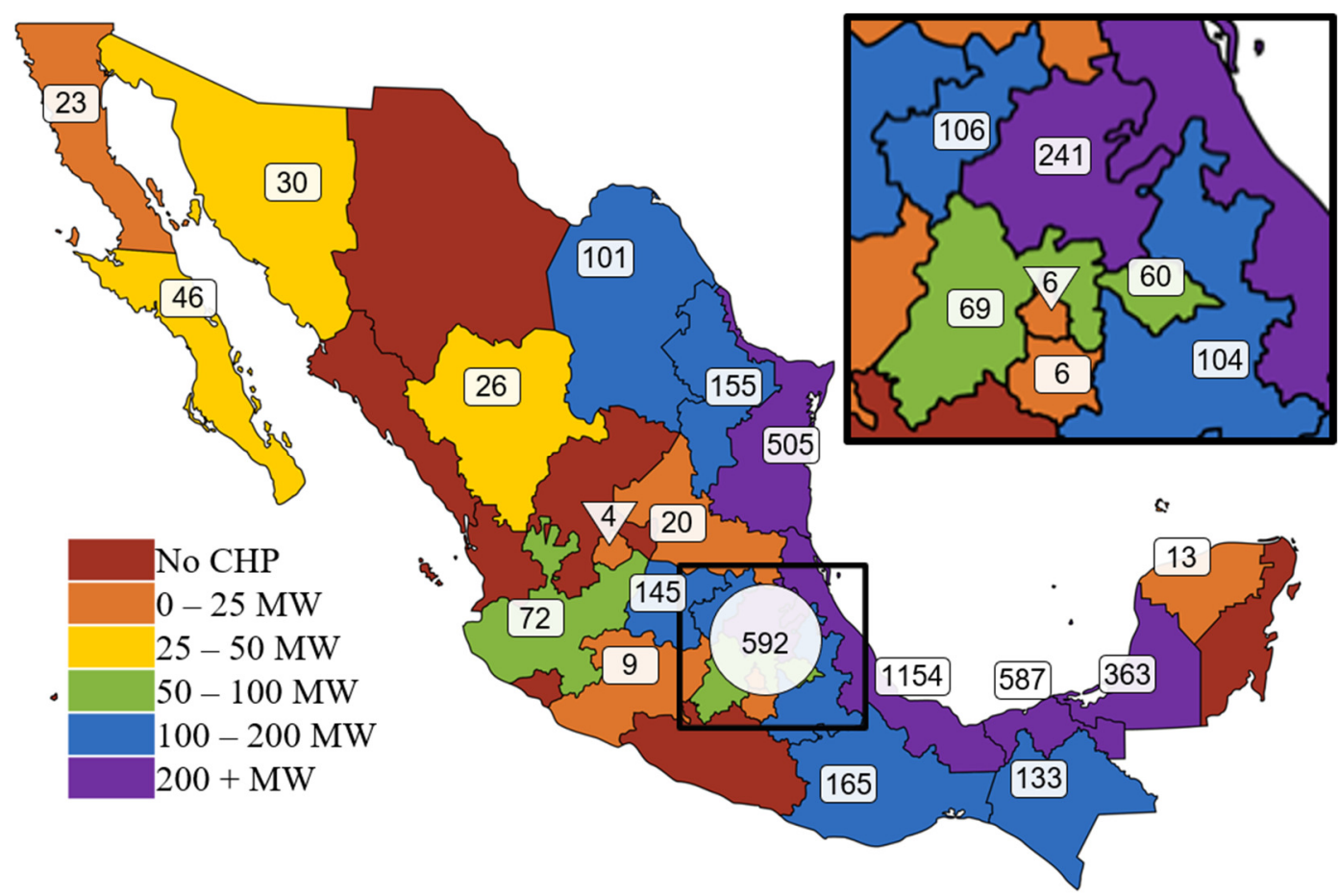

Figure 14. Distribution of all operational cogeneration permits (Secretaría de Energía de México 2017c; Comisión Reguladora de Energía 2016c). 


\subsubsection{Recent Market Activity}

CHP project development in Mexico was intense between 2012 and 2015 but has slowed down since then. We present several case studies in Figure 15 (Mosseri 2018), Figure 17 (Power Technology n.d.), Figure 19 (2G Cenergy n.d.), Figure 20 (CMPC 2015), showcasing U.S. company CHP installations in Mexico. The opening of the power sector for private development and increased access to natural gas should further accelerate the trend toward CHP development in the future. In 2015, PEMEX created a subsidiary, PEMEX Cogeneration, to further integrate CHP projects into its refineries and petrochemical plants, selling its surplus electricity to the grid (Robles 2016). Additionally, CFE is increasing its holdings in natural gas.

One measure of market activity is the granting of CHP permits by CRE since the reforms of 1992 . Figure 16 presents the permits granted and added capacity each year since 1994. While not all the approved permits have started operations, the permits provide a measure of the level of market activity and user interest in CHP. The period between 2013-2017 accounts for 44\% of the CHP permits granted by CRE and $14 \%$ of all generation permits granted in the same period.

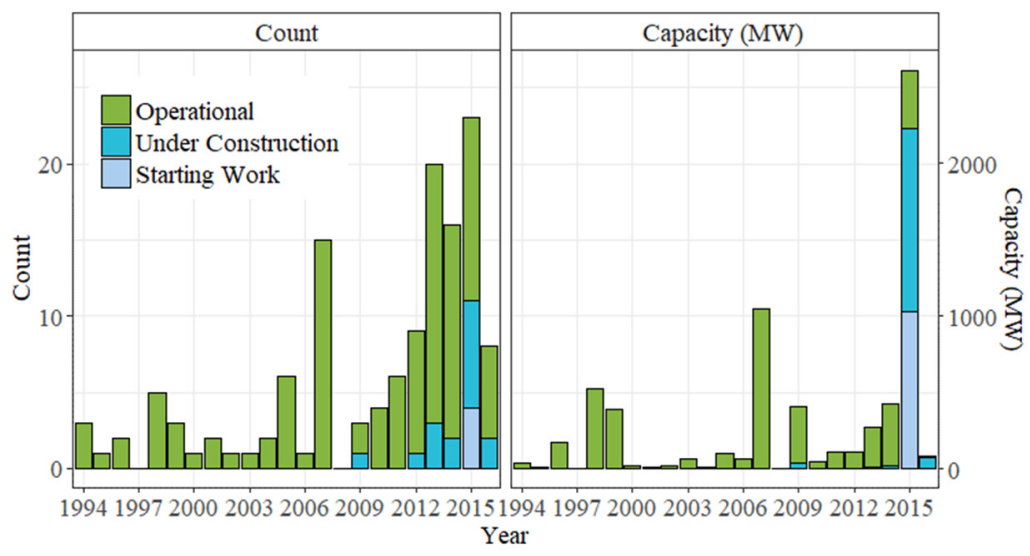

Figure 16. Count and capacity of all issued cogeneration and efficient cogeneration permits by year granted (Comisión Reguladora de Energía 2018).

\subsection{CHP MARKET POTENTIAL}

In order to meet the ambitious clean energy goals set forth by the LTE, Mexico must increase power generation from clean energy sources. Given this goal, Mordor Intelligence estimates the cumulative CHP capacity to reach 6.95 GW by 2022 .

PRODESEN-2017 is more conservative in its estimate, expecting $5.57 \mathrm{GW}$ by 2022 (current total CHP capacity plus the 
projected annual increases in capacity), eventually reaching $9.53 \mathrm{GW}$ by 2031 (Figure 18). However, the more recent PRODESEN-2018 estimates fewer efficient CHP additions in the coming years, reducing the 2022 estimate to $4.8 \mathrm{GW}$ and the 2032 estimate to only $6.5 \mathrm{GW}$. Conversely, PRODESEN-2018 expects combined cycle to be $42 \%$ of the added capacity between 2018 and 2032 (up from last year's expectation of $34 \%$ of the added capacity between 2017 and 2031), reaching $54.5 \mathrm{GW}$ by 2032 (Secretaría de Energía de México 2018) (up from 27.3 GW in 2016 [Secretaría de Energía de Mexico 2017c]).

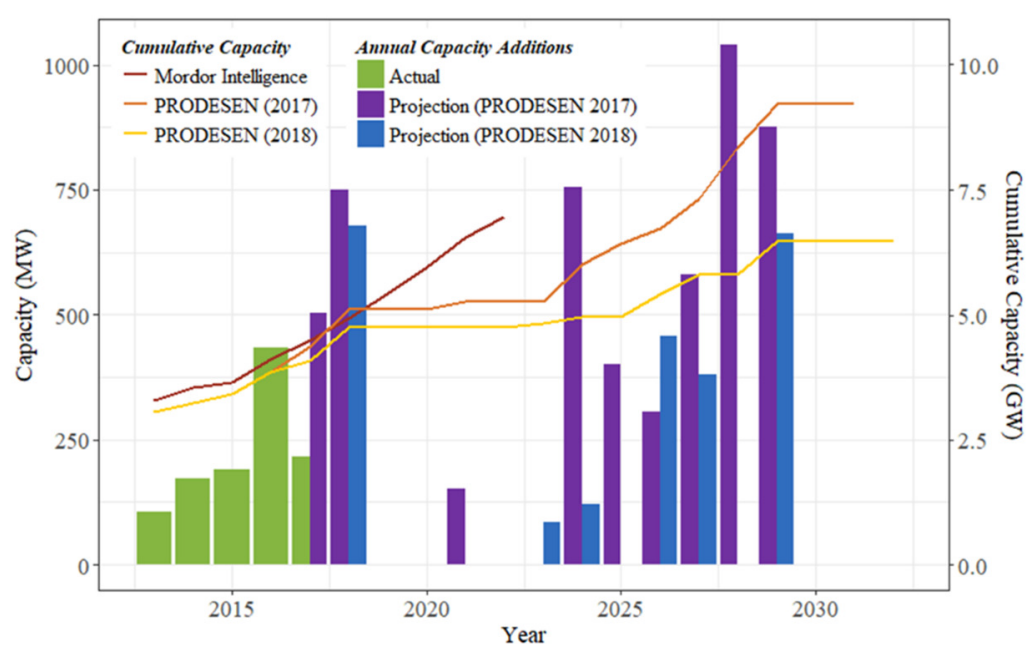

Figure 18. Added capacity (by year expected to begin operation) and projected cumulative CHP capacity (Secretaría de Energía de México 2017c; Mordor Intelligence 2017; Secretaría de Energía de México 2018).

The most important markets for CHP are the industrial and commercial sectors, both requiring electricity and heat (or cooling).

- Industrial sector - represents $32 \%$ of domestic energy consumption (60\% electricity) (Figure 11). Iron/steel (4.6\%), chemicals $(2.0 \%)$, cement $(3.5 \%)$, and mining $(1.3 \%)$ are primary energy users (Secretaría de Energía de México 2017b).

○ PEMEX - represents $1.2 \%$ of domestic energy consumption, down from 2014 (2\%) (Secretaría de Energía de México 2017b). More than $90 \%$ of PEMEX energy demand is concentrated in 18 facilities (six refineries, six gas processing plants, six petrochemical plants). PEMEX

General Electric - 2012 - Oil Refining
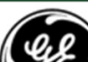

(\%) GE Power

Nuevo PEMEX

Villahermosa, Tabasco

System

Two GE-7FA multi-shaft gas turbines with:

- Advanced compressor

- DLN 2.6 Combustor

- Advanced hot gas path

Function

- The cogeneration plant should cover $55 \%$ of the Nuevo PEMEX complex steam demand.

- $300 \mathrm{MW}$ and 800 tons of steam per hour

Notes

- Will reduce $\mathrm{CO}_{2}$ emissions by 940,000 tons

- Two heat recovery steam generators supplied by

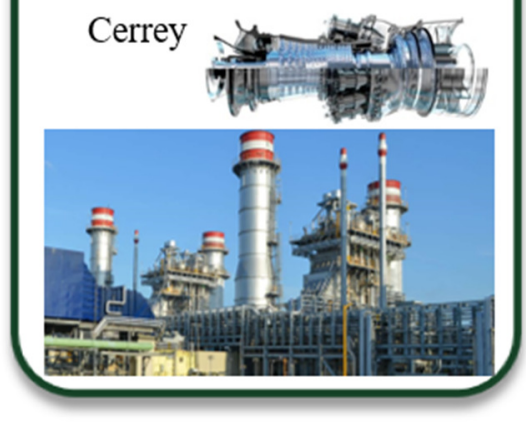

Figure 17. Case study - General Electric. has also formed a subsidiary devoted to cogeneration within their facilities.

○ Sugar industry - represents $0.7 \%$ only of domestic energy demand (Secretaría de Energía de México 2017b) but provides an excellent opportunity for CHP due to bagasse's (sugar cane pulp) potential as a fuel.

- Commercial sector - such as data centers, malls, hotels, and hospitals, represents 3\% of domestic energy consumption ( 9 - 20\% electricity) (Secretaría de Energía de México 2017b). This is the fastest 
- growing sector, due to the economic development across Mexico and increasing demand for air conditioning (Mordor Intelligence 2017). Additionally, this is a highly dispersed market in terms of size and energy use, and regional concentration is in the major cities.

In 2009, before the recent reforms, CONUEE and GIZ conducted a study [Comisión Nacional para el Uso Eficiente de la Energía (CONUEE), Comisión Reguladora de Energía (CRE), and Gesellschaft für Technische Zusammenarbeit (GTZ) 2009)] on the potential of cogeneration, focusing on three important sectors (i.e., general industrial, PEMEX, and the sugar industry). The study determined the maximum potential of each sector, but only assumed that the Industrial category could sell surplus power to SEN (Table 6).

Table 6. CHP potential in Mexico. ${ }^{a}$

\begin{tabular}{lc}
\hline Sector & Maximum potential (MW) \\
\hline Industrial & 6,085 \\
Sugar & 979 \\
PEMEX & 3,100 \\
Total & 10,164 \\
${ }^{a}$ Comisión Nacional para el Uso Eficiente de la Energía (CONUEE), \\
$\quad$ Comisión Reguladora de Energía (CRE), and Gesellschaft für \\
$\quad$ Technische Zusammenarbeit (GTZ) 2009).
\end{tabular}

Since 2009, the oil (403 MW) and sugar (115 MW) industries have only added $518 \mathrm{MW}$ of new CHP capacity, while the paper and pulp (116 MW), food processing (38.5 MW), textile (43.9 MW), chemical and petrochemical (11.5 MW) and "other" industries (1033 MW) together have absorbed most of the cogeneration market share (Secretaría de Energía de México 2017c; Comisión Reguladora de Energía 2017b). Figure 21 compares the permits granted after 2009 to the CONUEE-GIZ study's estimated market potential, revealing the unfulfilled potential in both the oil and sugar industries. Operational "industry" sector CHP installations since 2009 are approximately $62 \%$ of their "economic potential" (Figure 21). Including permits that have been granted but are not yet operational ("Under Construction" or "Starting Work") results in $57 \%$ of what the CONUEE-GIZ study determined to be the maximum potential of non-oil or sugar industries' potential realized. However, not much capacity is added when including non-operational permits, oil or sugar permits, leaving a lot of potential in those areas.
2G Cenergy - 2014 Animal Food Manufacturing

$2 \beta$ CENEREY

Lagunero Alimentos

Balanceados Simón Bolivar Torreon, Coahuila

\section{System}

All-in-one, plug-and-play

solution, packaged in a soundattenuated container, minimizes the use of floor space, allows for easy access

\section{Function}

- Operates continuously, producing $400 \mathrm{~kW}$ of electricity and $567 \mathrm{~kW}$ of heat

Notes

- Total efficiency 90\%

- Electrical efficiency $\sim 37.6 \%$

- Installation time $\sim 3$ days

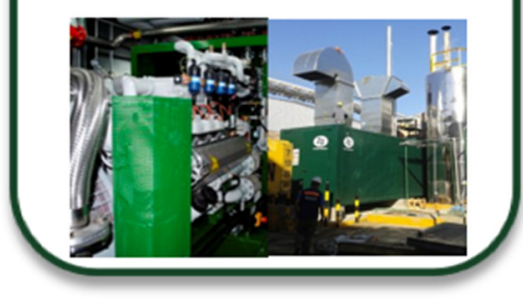

Figure 19. Case study - 2G Cenergy. and operability 
In a more recent estimate, the 2018 PRODESEN forecasts that efficient cogeneration will account for $3.6 \%(2.38 \mathrm{GW})$ of the capacity installed between 2018 and 2032 (reduced from the 10\% between 2017 and 2031 predicted in the previous year's report) (Secretaría de Energía de México 2017c, 2018).

Projections for cogeneration potential based on geographic location are compared in Figure 22 and Figure 23. Figure 22 illustrates the economic potential of the industrial sector as determined by the CONUEE-GIZ study (Table 6); Figure 23 shows the 2018 PRODESEN geographic forecast. Some states are unexpectedly installing CHP units (e.g., Nayarit and Chiapas), while other states will continue to have unfulfilled potential (e.g., Chihuahua, Sinaloa, Aguascalientes, Colima, Tlaxcala, Morelos, and Michoacán). Conversely, the east coast is planning installations far above what was expected.

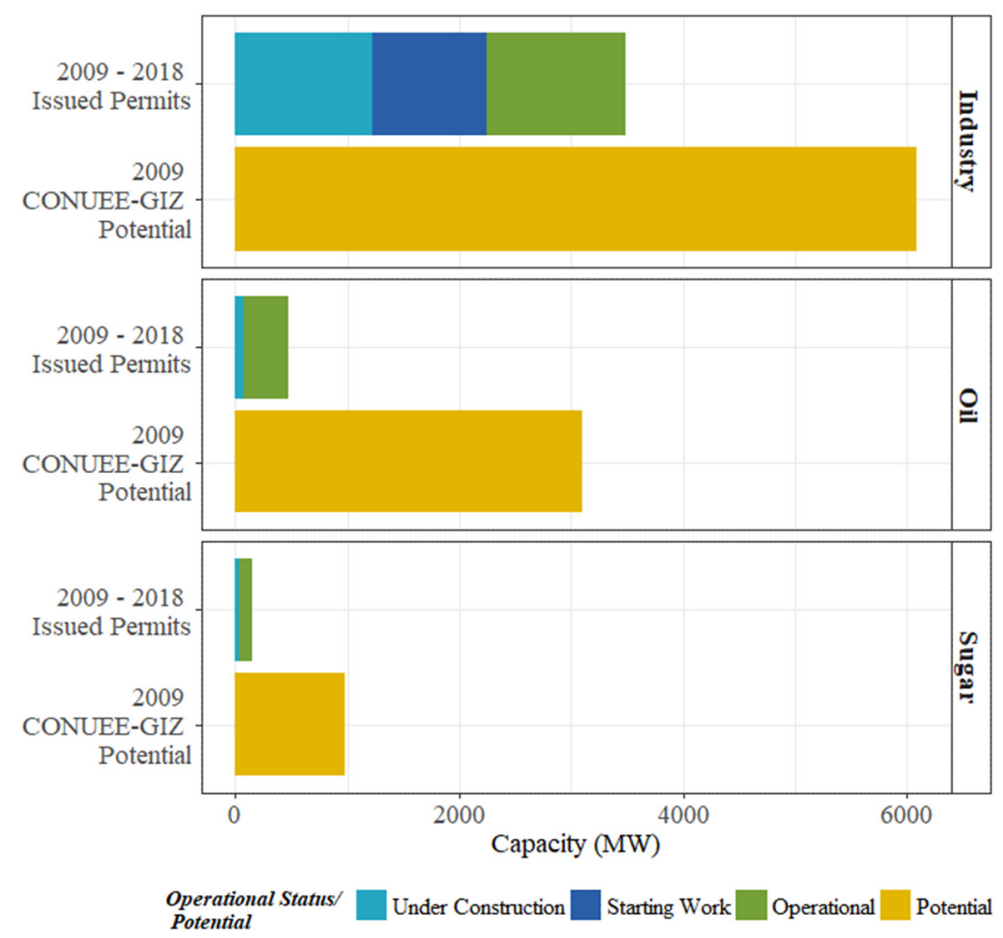

Figure 21. Comparison of CONUEE-GIZ study and cogeneration permits granted after 2009 [Comisión Reguladora de Energía 2018, Comisión Nacional para el Uso Eficiente de la Energía (CONUEE), Comisión Reguladora de Energía (CRE), and Gesellschaft für Technische Zusammenarbeit (GTZ) 2009].

Solar Turbines - 2016 Paper Manufacturing

Solar Turbines

A Caterpillar Company

CMPC Absormex

Altamira, Tamulipas

\section{System}

Titan $250+$ Solar Turbines

Insight Platform

- Combines remote monitoring technology and service specialist incountry to enable efficient machinery management and enhanced equipment assessment capabilities

Function

- Replaces almost all purchased electricity

- Turbine exhaust used for steam and direct heat

- $23.1 \mathrm{MWe} \& 75$ tons steam / hour

Notes

- CHP Interconnection permit under new regulations

- CHP registered as Efficient Cogeneration

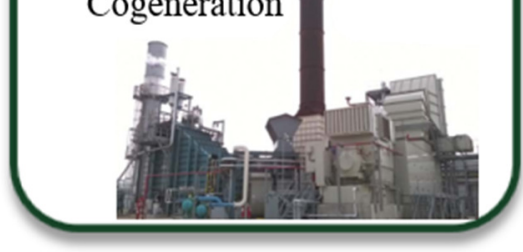

Figure 20. Case study - Solar Turbines. 


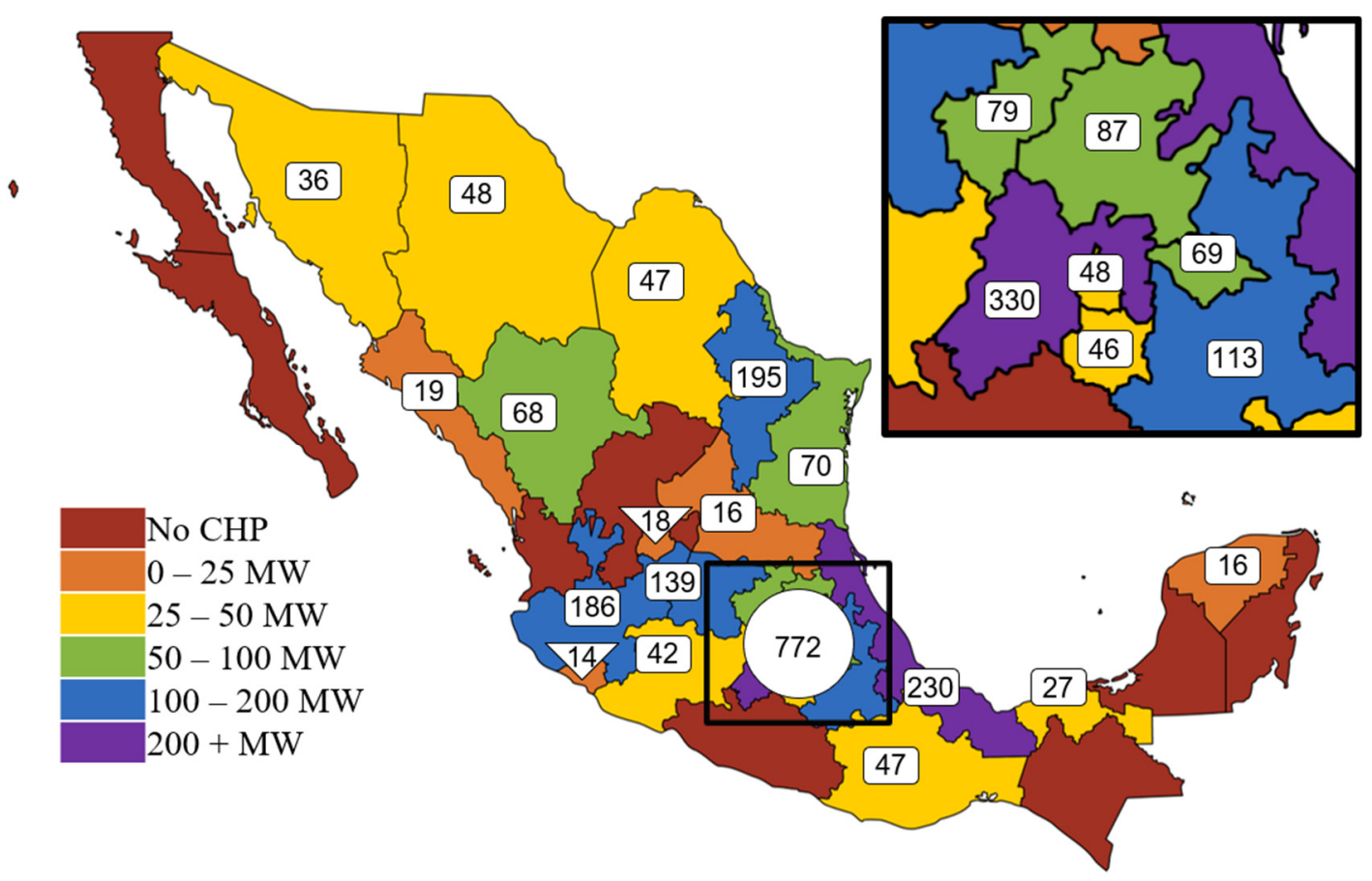

Figure 22. Geographic distribution of industrial economic potential for cogeneration (in MW of installed capacity) [adopted from Comisión Nacional para el Uso Eficiente de la Energía (CONUEE), Comisión

Reguladora de Energía (CRE), and Gesellschaft für Technische Zusammenarbeit (GTZ) 2009].

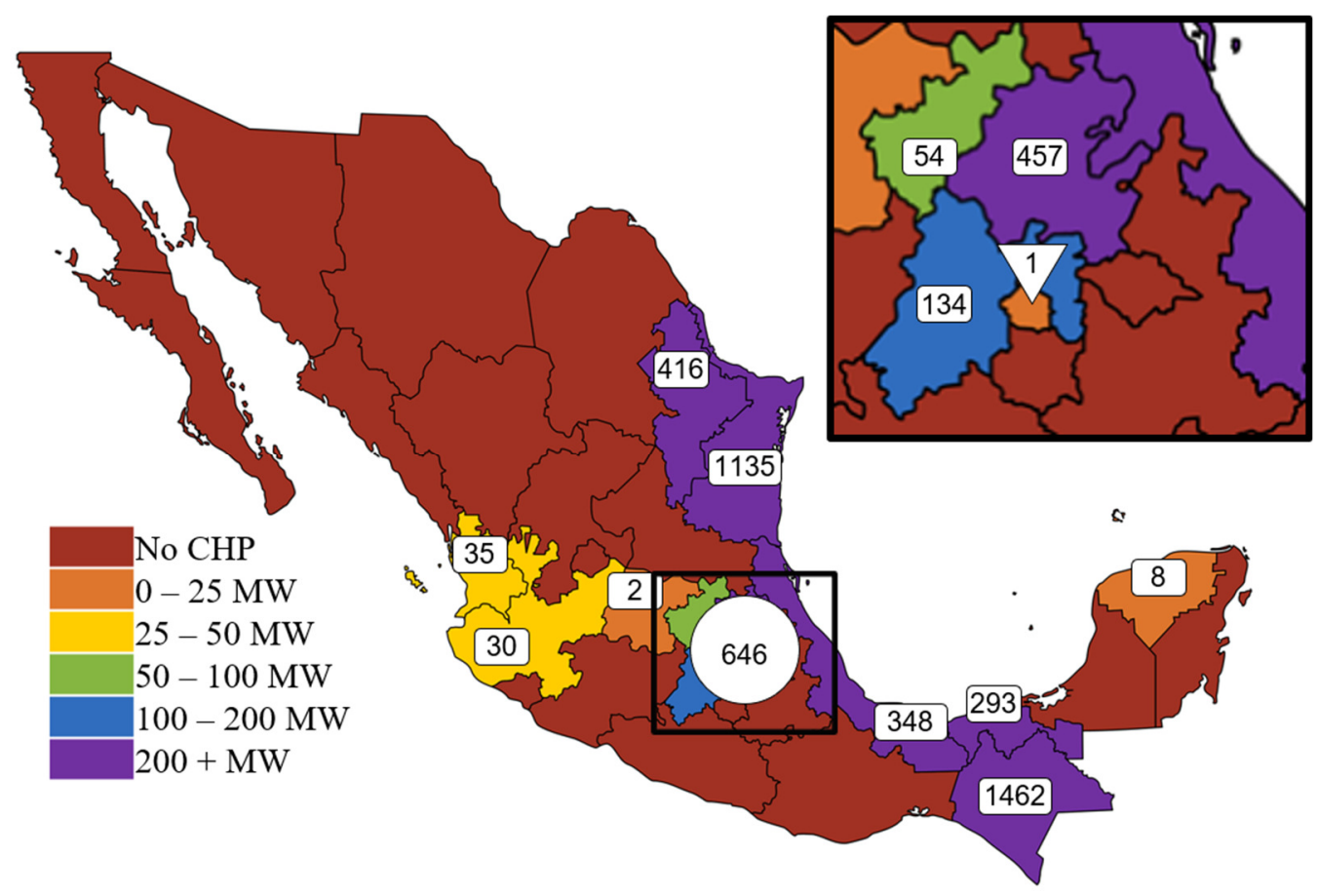

Figure 23: Geographic distribution of all cogeneration plants expected to come online between 2018 and 2032 (Secretaría de Energía de México 2018; Comisión Reguladora de Energía 2018). 


\section{CHP MARKET OPPORTUNITY SPACE IN MEXICO}

Several factors contribute to the growing opportunities for CHP developments in Mexico.

\subsection{GROWING ELECTRICITY DEMAND}

Electricity consumption in Mexico is expected to grow to between $451 \mathrm{TWh}$ and $522 \mathrm{TWh}$ (2017 generation was $329 \mathrm{TWh}$ ) by 2032 (Secretaría de Energía de México 2018). While energy production is currently expected to match overall demand, even now peak demand often exceeds the capacity of the transmission network (Mordor Intelligence 2017). Based on this trend, users will need to reduce or stop electricity use during peak hours, posing an energy supply risk to industrial consumers. Self-supply, especially CHP, could reduce or eliminate the dependence on grid electricity, decrease the risk of forced downtime, and minimize demand on the grid, increasing the resiliency of the connected process (Mordor Intelligence 2017). CHP also reduces the electricity demand for steam or heat generation (as this is a product of CHP installations), and overall improves the reliability of a facility's power supply.

\subsection{GROWING CLEAN ENERGY MARKET}

After the Paris Climate Agreement, Mexico vowed to reduce its GHG emissions by $22 \%$ below baseline by 2030. Additionally, the Energy Transition Law (Congreso de la Unión 2015) was announced, including a clean energy target of $25 \%$ for electricity generation by $2018,30 \%$ by 2021 , and $38.6 \%$ by 2032 (again, cogeneration is included in the definition of clean energy; see Figure 24). Experts expect $25.5 \%$ of clean energy investments made between 2016 and 2030 to be CHP, the same as solar PV and slightly less than wind energy (Mordor Intelligence 2017), although PRODESEN-2018 is only expecting $3.6 \%$ of the capacity additions to be efficient CHP (Secretaría de Energía de México 2018).

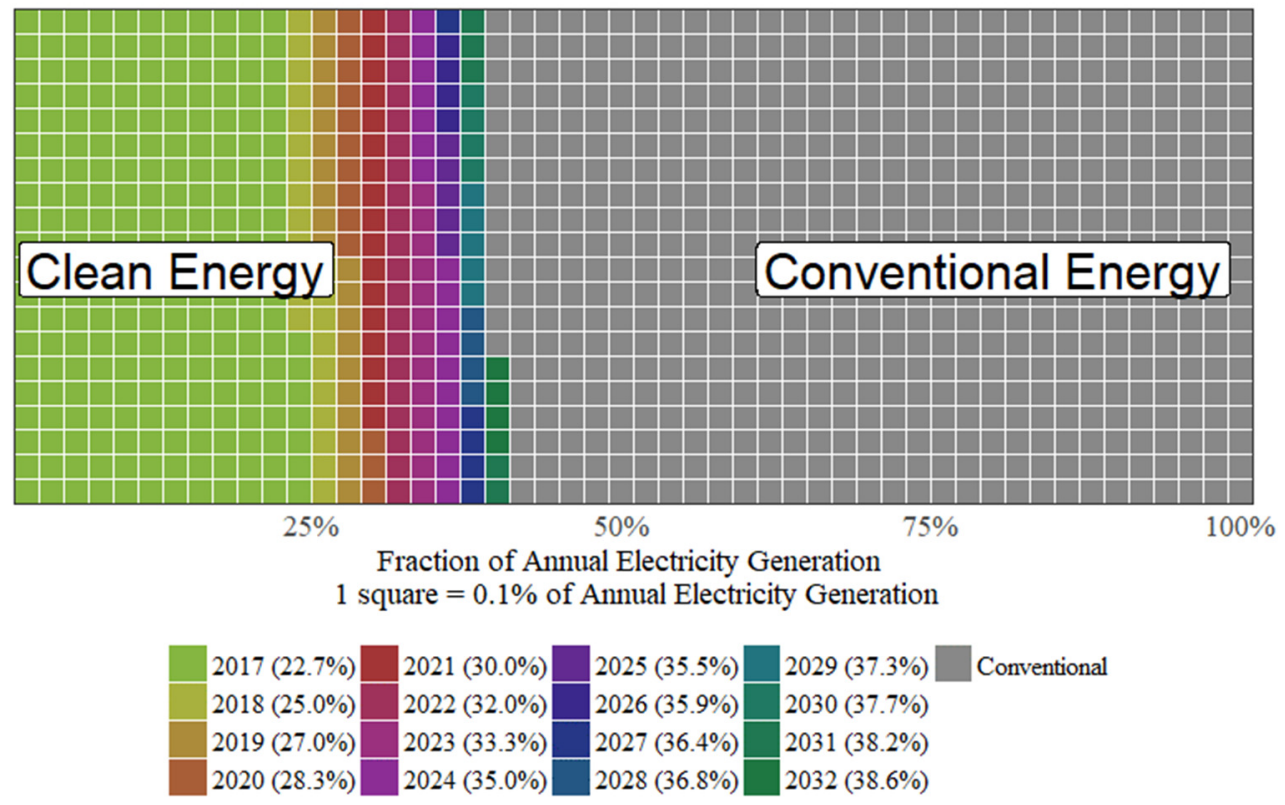

Figure 24. Legally mandated fraction of clean energy in the Mexican portfolio increasing to $38.6 \%$ by 2032 (Secretaría de Energía de México 2018).

The energy sector reform established that a CEL market be implemented by 2018. Large energy consumers will be required to meet an increasing minimum fraction of clean energy consumption via the CELs (5\% in 2018, 5.8\% by 2019), as established by SENER; fines for noncompliance will range from 
US\$27 to \$230 per MWh (International Energy Agency 2017). Clean energy producers (generators with low GHG emissions, e.g., renewable power, new nuclear power and efficient CHP generators) will earn one CEL for every MWh generated without the use of fossil fuels. This calculation is slightly more complex for cogeneration, earning $1 \mathrm{CEL}$ for every MWh generated above the minimum efficiency required to be considered efficient (Section 1.3) (Comisión Reguladora de Energía 2016c). CELs have a 20 year shelf life and have only been available via long-term contract auction, where the average price was US\$16.44 per CEL in the first auction and US\$13.08 per CEL in the second (Alvarez et al. 2016). While not yet available in the open market, they will soon be required for large-scale energy users (Martínez 2016). Self-generation of clean energy will reduce or eliminate the need to purchase CELs on the open market.

Mexico has also recently introduced a carbon tax on various fuels used for electricity generation (e.g., propane, butane, gasoline, diesel, etc.) which excludes natural gas and biofuels. As these are two major fuels for CHP in Mexico, CHP users can avoid paying additional taxes on fuels used to generate electricity (Vietor and Sheldahl-Thomason 2017).

\subsection{ENERGY REFORMS}

Due to the significant impact of fuel price on the cost of electricity, the lower price of natural gas (due to shale gas exports from the United States) and the qualification of cogeneration as clean energy, cogeneration cycles are gathering significant interest. In June 2015, PEMEX capitalized on the rising potential of cogeneration and created a cogeneration subsidiary-PEMEX Cogeneration and Services. PEMEX cogeneration and services can utilize the heat and steam generated by PEMEX oil refining by incorporating CHP units and potentially generating additional income by entering the wholesale electricity market. Additionally, PEMEX is planning $10 \mathrm{GW}$ of CHP projects within the next few years (Mordor Intelligence 2017). The regulation reforms and increasing abundance of natural gas are not only opening the way for increased PEMEX cogeneration, but for private entities as well. After the recent reforms, private companies can build and own their own pipelines under certain regulatory conditions, making it easier to obtain natural gas for CHP projects.

\subsection{OTHER SECTORS: SUGAR, COMMERCIAL, DATA CENTERS, OFF-GRID}

CHP has all the perks of distributed generation (e.g., reduction of congestion on T\&D network, greater energy autonomy, increased reliability) and clean energy (e.g., generating CELs, reducing carbon footprint), in addition to producing cooling, hot water or steam, making it a great fit in many sectors. Cogeneration is underutilized in the sugar industry. Following the 2014 regulatory reforms, cogeneration in this sector can earn more efficiency credits and additional incentives such as CELs because sugar bagasse is considered a sustainable fuel. As shown in Section 2.3, thus far, the sugar industry has not applied for many cogeneration permits.

There may also be opportunities in the commercial sector, such as data centers utilizing micro-CHP to produce electricity from the heat generated by the systems or in commercial buildings (e.g., hospitals, restaurants, hotels, malls) that need hot water and cooling. The commercial sector is currently the fastgrowing energy user in Mexico, due to the increasing sector size (more malls, hotels, hospitals, etc.) and the increasing demand for air conditioning in those facilities (Mordor Intelligence 2017).

CHP systems can also be an efficient option for off-grid systems. In Mexico, there are still many rural areas without reliable access to the national grid; CHP units can provide reliable electricity and heat to homes, schools, and medical clinics in these remote areas. 


\subsection{MODES OF ENTRANCE FOR CHP DEVELOPERS AND POWER PRODUCERS}

The Mexican CHP market could provide new investment opportunities for U.S. companies because of its proximity, resource potential, and the existing free-trade agreement between the two nations. These advantages may be amplified at every level of the value chain by the recent energy reforms and the country's substantial clean energy goals. For manufacturers of generating sets, turbines, and balance-ofplant components, the geographic proximity between the United States and Mexico and the North American Free Trade Agreement (NAFTA) may result in a strategic advantage, particularly over European competitors. The energy reform also creates new opportunities for private developers and independent power producers as described below.

Mexican primary energy demand is expected to increase by about $20 \%$ by 2040 (over its 2014 demand) (Baritau et al. 2016), while electricity demand is expected to grow by $85 \%$. Cogeneration systems are expected to contribute 3.6\% of the electrical capacity installed between 2018 and 2032 (Secretaría de Energía de México 2018); this calls for additional investments in cogeneration and waste heat recovery.

There are several modalities in which private sector energy developers and power producers, ${ }^{6}$ domestic and foreign, can do business in the Mexican electricity market. In general, developers can partner with or build turnkey plants for companies that are currently operating in Mexico or independently develop and operate new projects. Private power producers can bid in electricity auctions, sell their output in the wholesale market, or enter into bilateral contracts with CFE's generation subsidiaries, power marketers, and private, large-scale consumers (Figure 25).

\footnotetext{
${ }^{6}$ In this paper, a developer is the entity that coordinates or executes the development of a power project before operations. Power producers are the entities that own the plant during its operational life. Often, developers continue ownership of plants after they come online, thus becoming power producers.
} 


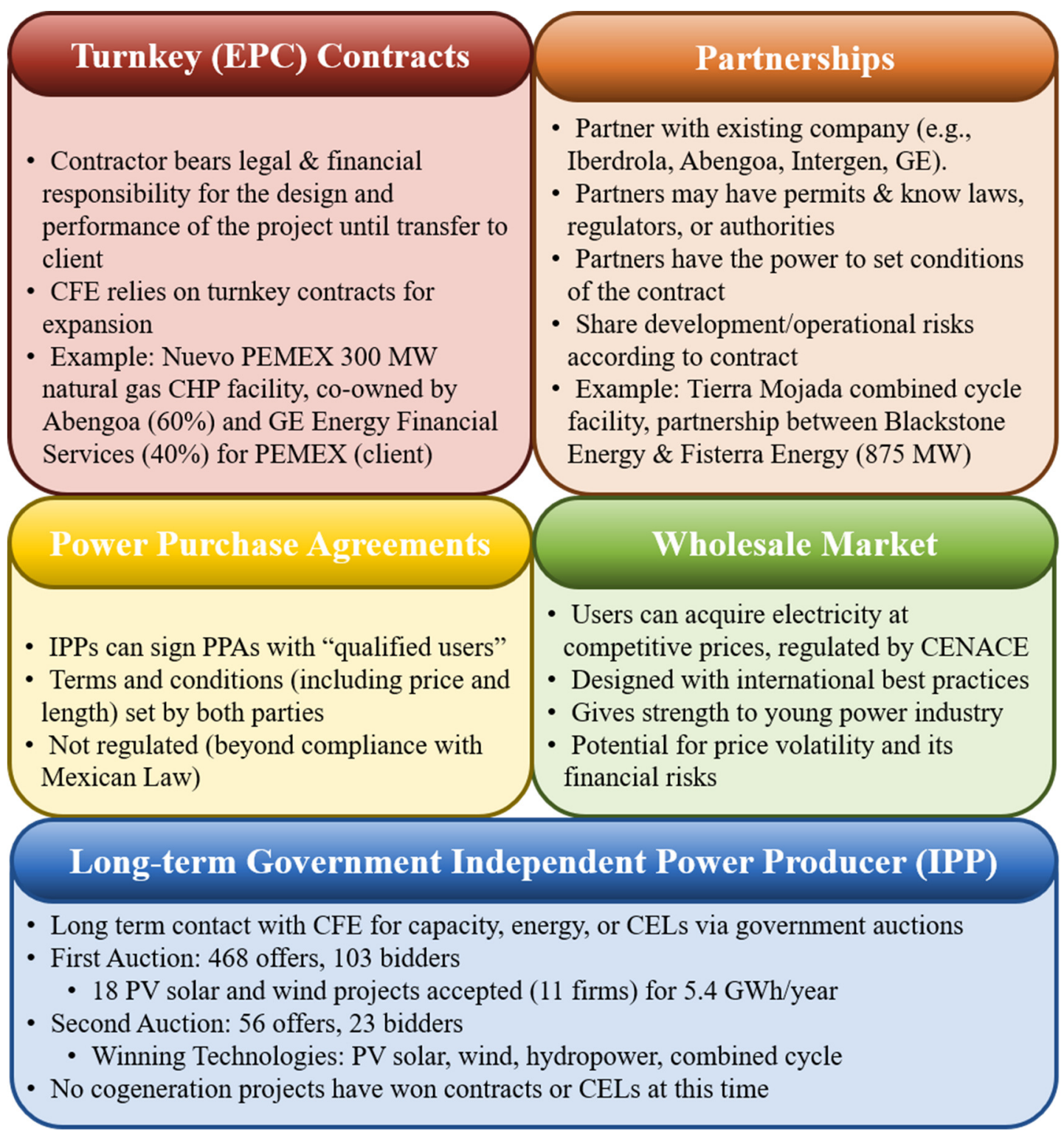

Figure 25. Modes of entrance for CHP developers and power producers (Chirhart 2017; Power Technology n.d.; KPMG 2016; Secretaría de Energía de México 2016a; Martínez 2016).

\subsubsection{Partnerships}

A potential opportunity for project developers interested in the Mexican market involves partnering with companies that currently have a presence in the local cogeneration market (e.g., Iberdrola, Mistui, Gas Natural Fenosa, ENEL, SEISA, Abengoa, Intergen, GE). In a partnership, all parties share development and operation risks according to criteria established in the relevant contracts. Partnerships can be advantageous because locally active companies may already have permits and know the local laws, regulations, and relevant authorities. On the other hand, locally active companies have the power to set the partnership conditions or decide not to partner at all (Flores-Espino, Booth, and Graves 2017).

In general, potential partners presenting unsolicited offers to CFE or other companies could increase their chances by presenting structured and detailed proposals, finding off-takers for the energy contracts, or bringing financing resources to the partnership (Flores-Espino, Booth, and Graves 2017). The Tierra 
Mojada combined-cycle gas turbine power plant in Guadalajara is an example partnership between Blackstone Energy and Fisterra Energy that produces 875 MW of energy (Chirhart 2017). Abengoa's 924 MW combined cycle Norte III power plant in Juárez, Chihuahua, will become the largest combinedcycle power plant in Mexico upon completion in 2018 (Abengoa 2015).

\subsubsection{Turnkey Contracts}

Turnkey — or engineering, procurement, and construction (EPC) — is a form of contracting where the contractor bears the legal and financial responsibility for the design and performance of the project until it is transferred to the client. In general, CFE requests proposals from different vendors and selects one offer according to predetermined criteria (Flores-Espino, Booth, and Graves 2017). Recent turnkey projects include the construction of Empalme I, between SENER and OHL Industrial (OHL Industrial 2015), and the Nuevo PEMEX plant.

The Nuevo PEMEX 300 MW gas-powered CHP facility cost around US\$640 million and was launched in October 2012. A 20-year contract plant, Abengoa owns a 60\% share of the facility and GE Energy Financial Services owns $40 \%$. The total sale of electricity and steam from this plant over the contract period is estimated to be approximately US $\$ 2.2$ billion. The cogeneration technology used will cut $\mathrm{CO}_{2}$ emissions by 940,000 tonnes by 20 years (Power Technology n.d.).

\subsubsection{Long-term Government IPP Contracts}

Independent power producers (IPPs) can enter into long-term electricity contracts with CFE-in its role as a power provider for end consumers - through government-led auctions. In these auctions, SENER and CENACE offer 15 year contracts for energy and capacity and 20 year contracts for CELs in annual auctions (Vietor and Sheldahl-Thomason 2017).

The government of Mexico announced the winners of its first long-term electricity contract auction in March 2016, which proved to be very competitive. SENER and CENACE received 468 offers from 103 bidders offering 16 times the energy requested. Proposed technologies included geothermal, solar PV, wind, hydro, combined cycle, and cogeneration (Energía 2016). The winning bids include 18 projects from 11 firms, totaling an estimated energy production of $5.4 \mathrm{GWh}$ per year. Of that total, 74\% was awarded to solar PV projects and the rest to wind projects.

The winning bids for Mexico's second long-term contract auction were announced in September 2016. Fifty-six projects from 23 companies were awarded contracts for CELs, energy, capacity, or a combination of the three. Of the total energy awarded, $54 \%$ went to solar projects and $43 \%$ to wind. Winning technologies also included hydropower, which took $3 \%$ of the total CELs contracted, and natural gas combined cycle, which received $72 \%$ of all capacity contracted (Secretaría de Energía de México 2016a). At this point, no cogeneration projects have won contracts or CELs at the long-term auctions and would only be likely to be used by large-capacity projects, such as by PEMEX Cogeneration.

\subsubsection{Power Purchase Agreements (PPAs)}

IPPs can sign PPAs, or Power and Steam Purchase agreements, with qualified users, defined by law to be commercial and industrial consumers with a peak demand of $1 \mathrm{MW}$ or more and registered with the CRE. PPA terms and conditions, such as length and price, are set by the parties to the contract and are not regulated by the government, provided they comply with Mexican law. End users with a peak demand of at least $5 \mathrm{MW}$ and a yearly consumption of $20 \mathrm{GWh}$ or more can also procure electricity by themselves in the wholesale energy market. 
In principle, new CFE generation subsidiaries can sign PPAs directly with IPPs, even outside of the auctions. However, since the subsidiaries now compete with other producers, new PPAs increase CFE's risk and responsibility (for finding an off-taker). Therefore, for smaller CHP generation, this type of agreement is less likely compared with a partnership where the developer and CFE subsidiaries work together to build the plant and find off-takers (Flores-Espino, Booth, and Graves 2017).

\subsubsection{Participation in the Wholesale Market}

IPPs can also participate directly in the Mexican wholesale electricity market, which includes markets for energy and ancillary services. The energy reforms established a new wholesale electricity market, allowing the production sector to acquire electricity at competitive prices, and have a legal framework, allowing regulators to develop an efficient and competitive market. The market has been designed following international best practices, reducing the risk of committing past regulatory mistakes, but giving strength to the new power industry that still faces huge challenges ahead. IPPs participating in the wholesale market will be exposed to price volatility and its financial risks. The wholesale electricity market has a wider growth perspective due to Mexico's delay in adopting a structural reform in the energy sector. Price risk may also be managed through alternative hedging strategies, such as synthetic power purchase agreements where the risk is transferred to a third party (Flores-Espino, Booth, and Graves 2017). However, like PPAs, this mode is likely too risky for smaller CHP generations, given the high volatility of the spot market prices. 


\section{ENTRANCE BARRIERS}

While the opening of the energy sector to private investment has generated significant investment potential for CHP, there are still major barriers to implementing CHP projects. These are issues that were previously identified by a variety of sources and need to be reviewed and examined as part of the continuing dialogue. Some of these challenges are common to CHP development in other countries, while others are unique to Mexico.

Many of the barriers pertain to difficulty finding up-to-date information on regulations regarding permitting, interconnection, and efficient accreditation. There are also barriers pertaining to obtaining financing, corporate support, and natural gas and electricity pricing and availability. There is a general lack of knowledge to identify the correct assumptions and to account for all of CHP's benefits on a feasibility study. This permeates and compounds many of the other barriers identified.

A more recent barrier relates to the decreasing cost of electricity provided by the new energy auctions administered by CENACE. This lower price makes self-generation less economical; wind energy is being bid as low as US\$17.70 per MWh by foreign companies that can accept the reduced profits (Deign 2017). This price does not include T\&D costs, a CENACE and qualified service provider fee, capacity payment, or the cost of energy storage, potentially giving a lower impression of the true cost. However, users do not immediately see this cost and may not account for the primary benefits of CHP (e.g., steam or cooling and increased electrical reliability) when considering the economics of CHP installation. Additionally, the formula used by CFE to define the electricity rates changed in early 2018, creating uncertainties in the electricity market and decreasing the cost of electricity in some regions, reducing the competitiveness of CHP in those areas.

Many of these barriers can be overcome with more information. The CRE's website includes frequently asked questions for electricity permits (Comisión Reguladora de Energía 2016b), CELs (Comisión Reguladora de Energía 2016c), efficient accreditation (Comisión Reguladora de Energía 2016a), and many more. Organizations such as Cogenera are actively working to bring clarity to the permitting process and provide education and knowledge to their partners and others interested in CHP installation. Cogenera is also working to educate its industrial and commercial partners on the benefits of CHP.

Additionally, large international companies have begun CHP projects (e.g., GE, Techogen, Abengoa), increasing awareness and demand among the commercial and industrial sectors (Mordor Intelligence 2017). While they may not have CHP-specific educational programs, Mexican universities have begun to generate three times more engineering students, per capita, than the United States, which could increase the pool of technically capable workforce.

\subsubsection{Regulatory - Permitting}

- Difficult to find up-to-date information pertaining to permitting regulations and the permit application process

- More difficult to find information on permitting requirements beyond that established by CRE (e.g., municipal, environmental studies)

- Complex process to apply for permit

- High costs for applying for permit 


\subsubsection{Regulatory - Interconnection}

- Difficult to find current information on how to apply for interconnection and what is required

- Difficult to complete all interconnection studies in the mandated time frame

- High costs associated with interconnection studies, especially on a cost per MW scale for smaller CHP units.

\subsubsection{Regulatory - Clean Energy and CHP}

- Difficult to find up-to-date information on the determination of "efficient" and accreditation for individuals performing measurements for accreditation

- Difficult to find up-to-date information on the generation and obtaining of CELs

- CELs are not yet traded on the open market, providing lower incentive to generate them

\subsubsection{Financial}

- Financial providers lack the knowledge to evaluate project feasibility

- Lack of adequate sales and service infrastructure for small scale CHP

- Undeveloped CHP supplier and financing infrastructure

- Loan guarantees on primary business are required for project financing

- High upfront costs for CHP units

- Financial providers will only provide financing for the electricity and steam capacity that is guaranteed to be used. As most industrial CHP units are designed to meet steam demands, any excess electricity will need a signed PPA to obtain full funding for the project.

\subsubsection{Market Issues}

- There are few market incentives to help monetize CHP's primary benefits (e.g., reliability and steam production), making feasibility analysis and project approval more difficult.

- CHP not considered a "core" business concern, reducing corporate interest

- Lack of natural gas distribution infrastructure in many areas

- The historical low energy prices for natural gas and liquified petroleum gas (LPG) and fluctuating prices for electricity, combined with a relatively efficient electrical distribution grid, reduce the benefits of installing CHP.

- While PPAs and IPPs are valid modes of entrance to the energy market for CHP installations, the practicality is limited, and legal details are still being worked out.

\subsubsection{Information}

- Overall lack of knowledge of evaluation criteria and assumptions used with CHP pro forma financial analyses

- Perception by certain industries capable of cogenerating that the process for implementing successful cogeneration projects involves high risk and is of high technological complexity. 
- Renewable energy technologies are perceived to be less expensive, due to recent energy auction prices that do not account for transmission, distribution or other costs, or energy storage.

\subsubsection{Workforce}

- Few training programs are being offered within Mexico on cogeneration design, construction, and operation.

- A weak cogeneration market has not been able to create enough supply of trained technical personnel for the implementation and operation of cogeneration projects.

- It is difficult to identify public/private organizations dedicated to providing services for evaluating and measuring potential cogeneration projects.

- There are few technical resources to help address a growing demand for a workforce that can support the various stages of cogeneration project development and implementation, among which include research and analysis, project scoping and planning, installation, construction, control, operation, and maintenance.

- Universities, both public and private, have not strengthened or created a link to support cogeneration in Mexico; this includes a lack of developing technical staff and promoting cogeneration research. 


\section{MEXICAN GOVERNMENT PROGRAMS, RESOURCES, AND INCENTIVES}

\subsection{INVESTMENT GUIDANCE FOR FOREIGN COMPANIES}

The government of Mexico has established ProMéxico, an office dedicated to aiding foreign companies interested in pursuing business opportunities in Mexico. ProMéxico provides step-by-step guidance regarding all aspects related to conducting business in Mexico, from getting a visa and incorporating a business in Mexico to identifying investment and tax incentives applicable to specific situations.

ProMéxico has offices in 12 cities of the United States, and its agents can be contacted via chat through their website, www.promexico.mx (Flores-Espino, Booth, and Graves 2017).

\subsection{TAX INCENTIVES AND FINANCING MECHANISMS}

It is possible to obtain a full tax deduction for the machinery and equipment used for cogeneration of efficient electric power systems, depending on a review by the tax authorities (Serra and Escobedo 2017). The Mexican government has created new investment vehicles - and modified existing ones - to increase the availability of financing for energy projects, create legal certainty for investors, and simplify tax obligations. The first of the newly available vehicles, FIBRA E (infrastructure and real estate trusts), is based on the Real Estate Investment Trusts (REIT) used in the United States. FIBRA E trusts pay out the taxable income from their generation plants as dividends to shareholders. FIBRA E allows any investor to participate in renewable energy financing and possibly obtain a return on the investment through the purchase of stock (Grupo BMV, n.d.; Deloitte 2016). Thus far, no energy-related companies have used this tool, but experts expect more offerings to emerge in the coming years (LatinFinance 2017).

Another financing vehicle, the CerPI (investment project certificate), is designed to open access to sources of capital previously unavailable to clean energy project finance such as pension funds, insurance funds, and other foreign and domestic institutional investors. CerPIs are structured through Mexican trusts that issue investment certificates placed through a public offering on the Mexican Stock Exchange (Groenewold 2012; Deloitte 2016). FICAPs (investment trusts for private capital) are vehicles for private equity investment that provide the trust members with tax-transparent benefits; that is, trustees are taxed on the distribution received and not on the portion of the trust income to which the beneficiary is entitled. Their goal is to promote investment in companies that are not listed on the stock exchange at the time of investment. FICAP trusts used to have a time limit of 10 years, which limited their appeal to investors. The 2016 tax reform has eliminated that cap. As a result, energy projects with operational lives longer than 10 years can raise capital through these instruments (Grageda Nunez 2015; Deloitte 2016).

Mexican development banks, such as Banobras and Nafinsa, and multilateral development banks, such as the Inter-American Development Bank (IDB), the International Finance Corporation, and the North American Development Bank, could be a source of low-cost debt financing for clean energy projects in Mexico (Flores-Espino, Booth, and Graves 2017).

\subsection{CLEAN ENERGY CERTIFICATES}

As mentioned above, with the new reforms, the CRE is empowered to issue CELs, which are used to track compliance with the country's clean energy requirements (Section 3.2). Cogeneration-based power plants that produce clean energy are eligible to receive one CEL per MWh produced over the minimum efficiency necessary to qualify as efficient (Comisión Reguladora de Energía 2016c). 


\section{U.S. GOVERNMENT RESOURCES}

\subsection{INTERNATIONAL TRADE ADMINISTRATION}

The U.S. Department of Commerce's International Trade Administration (ITA) strengthens the competitiveness of U.S. industry, promotes trade and investment, and ensures fair trade through the rigorous enforcement of U.S. trade laws and agreements. ITA works to improve the global business environment and helps U.S. organizations compete at home and abroad. With offices throughout the United States and in U.S. embassies and consulates in nearly 80 countries, the U.S. Commercial Service utilizes its global network of trade professionals to connect U.S. companies with international buyers worldwide. Whether looking to make their first export sale or expand to additional international markets, companies will find the expertise they need to tap into lucrative opportunities and increase their bottom line. This includes trade counseling, actionable market intelligence, business matchmaking, and commercial diplomacy. Industry \& Analysis' (I\&A's) staff of industry, trade, and economic analysts devise and implement international trade, investment, and export promotion strategies that strengthen the global competitiveness of U.S. industries.

These initiatives unlock export and investment opportunities for U.S. businesses by combining in-depth quantitative and qualitative analysis with ITA's industry relationships. U.S. CHP companies interested in ITA's support can contact either a domestic office (https://www.export.gov) or the Foreign Commercial Services office located in the U.S. Embassy in Mexico City (https://2016.export.gov/mexico).

\subsection{DEPARTMENT OF STATE}

The U.S. Department of State (DOS) provides general resources about specific countries and markets. DOS staff located within the U.S. Embassy in Mexico City coordinates with ITA's Foreign Commercial Services staff to support U.S. exports to and investments in Mexico. In general, DOS encourages U.S. companies to contact Foreign Commercial Services directly, whose staff will bring in DOS experts as appropriate and based on the company's needs. The DOS staff can provide an economic and political overview of specific markets.

The U.S. Embassy in Mexico City launched a business opportunities website in April 2014 designed to support small and medium enterprises. The website, called "Opportunities in Mexico for U.S. Businesses and Investors," is located at https://mx.usembassy.gov/business/. This resource provides financial, economic, and political updates on issues related to U.S. business opportunities in Mexico. It also provides resources for businesses interested in exporting to or investing in Mexico. Though the information provided covers all sectors, there are many resources relevant to energy companies.

\subsection{OVERSEAS PRIVATE INVESTMENT CORPORATION}

The Overseas Private Investment Corporation (OPIC) supports U.S. businesses by providing medium- to long-term debt financing, political risk insurance, and investment support to companies expanding into emerging markets, including Mexico. OPIC can loan up to US\$250 million per project in countries where conventional financial institutions are reluctant or unable to lend due to market uncertainties. Eligible projects must have meaningful involvement with the U.S. private sector, which is often satisfied by at least $25 \%$ of the project company's equity coming from U.S. businesses, citizens, or lawful permanent residents.

OPIC's political risk insurance program helps U.S. companies, investors, lenders, contractors, exporters, and nongovernmental organizations reduce the risk of investing in a developing or emerging market by protecting tangible assets, investments, and earnings from losses that result from activities outside of the 
control of the investor. These activities could include war, political violence, expropriation, and currency inconvertibility (Flores-Espino, Booth, and Graves 2017).

Since 2010, OPIC has committed over US\$9.3 billion to renewable and other energy projects across the globe. OPIC's portfolio includes three main products, debt financing (medium- and long-term loans), political risk insurance, and support for investment funds. In Mexico, OPIC has committed US\$90 million to a $150 \mathrm{MW}$ wind facility and US\$15.5 million to a $15.5 \mathrm{MW}$ solar facility. Additionally, they hold several political risk insurance policies for CHP and combined cycle projects in Nigeria, Senegal, and Ghana (Overseas Private Investment Corporation 2018).

For more information, visit www.opic.gov/.

\subsection{EXPORT-IMPORT BANK}

The Export-Import Bank (Ex-Im) supports the export of U.S. products and services. Their Renewable Energy \& Environmental Exports Program is designed to provide financing for U.S. companies exporting renewables and environmental technologies and services, including CHP (Export-Import Bank of the United States n.d.). Through this program, Ex-Im provides the following financing support:

- $\quad$ short-term working capital,

- export credit insurance,

- medium-term insurance,

- medium- to long-term loan guarantees,

- $\quad$ projects and structured finance, and

- long-term direct loans

Additionally, transactions may be eligible for capitalized interest during construction and allowing for up to $30 \%$ local cost financing. Ex-Im can offer 7-10 loan repayment for CHP projects.

To learn more and to contact an Ex-Im Bank representative directly, visit www.exim.gov/learningresources.

\subsection{U.S. TRADE AND DEVELOPMENT AGENCY}

The U.S. Trade and Development Agency (USTDA) helps link U.S. technologies and services to priority infrastructure opportunities in emerging economies. The agency does so by funding technical assistance, feasibility studies, and pilot projects and by hosting reverse trade missions to the United States for project sponsors from partner countries. Public-sector (federal, state, and local) and private-sector host country project sponsors may be eligible for USTDA support. The energy sector is a particular priority for USTDA. Additional information is available at https://www.ustda.gov/. 


\section{REFERENCES}

2G Cenergy. n.d. "Intelimeter.” Accessed March 9, 2018. http://www.2genergy.com/projects/intelimeter/.

Abengoa. 2015. “Combined Cycle Norte III - 924 MW.” 2015. http://www.abengoa.com.mx/web/en/areas-de-actividad/infraestructuras-tipoconcesional/obra/Combined-Cycle-Norte-III-924-MW/.

Alvarez, Alfredo, Rafael Aguirre, Rodrigo Fernandez, Loic LeGall, Jimena Gonzalez de Cossio, and Paul Roberti. 2016. "Energy Alert - National Electric System Development Program (PRODESEN) 2016-2030.” http://www.ey.com/Publication/vwLUAssets/ey-energy-alert-prodesen-20162030/\%24FILE/ey-energy-alert-prodesen-2016-2030.pdf.

Alvarez, Alfredo, Rafael Aguirre, José Salas, Loic LeGall, and Paul Roberti. 2017. "Energy Alert National Electric System Development Program (PRODESEN) 2017-2031." http://www.ey.com/Publication/vwLUAssets/ey-energy-alert-national-electric-system-developmentprogram-2017-2031/\$File/ey-energy-alert-national-electric-system-development-program-20172031.pdf.

Baritau, Manuel, Elie Bellevrat, Hannah Daly, Nathan Frisbee, Markus Klingbeil, Olivier DurandLasserve, Rodolfo Lobato, Kristine Petrosyan, and Brent Wanner. 2016. "Mexico Energy Outlook." https://www.iea.org/publications/freepublications/publication/MexicoEnergyOutlook.pdf.

Centro Nacional de Control de Energía. 2015. Criterios Mediante Los Que Se Establecen Las Caracteristicas Especificas de La Infraestructura Requerida Para La Interconexión de Centrales Eléctricas Y Conexión de Centros de Carga. Mexico: Diario Oficial de la Federación. http://www.dof.gob.mx/nota_detalle.php?codigo=5394833\&fecha=02/06/2015.

Centro Nacional de Control del Gas Natural. 2016. "Revisión Anual Del Plan Quinquenal de Expansión Del Sistrangas 2015-2019.” https://www.gob.mx/cenagas/es/articulos/mapa-de-la-red-degasoductos-que-conforman-el-sistrangas?idiom=es.

Chirhart, Paula. 2017. "Blackstone Energy Partners and Fisterra Energy Announce the Financial Closing of the Tierra Mojada Power Plant in Guadalajara, Mexico." Business Wire, June 23, 2017. https://www.businesswire.com/news/home/20170623005537/en/Blackstone-Energy-PartnersFisterra-Energy-Announce-Financial.

CMPC. 2015. "Sustainable Development Report 2015." http://ir.empresascmpc.cl/English/Sustainabilityand-Governance/Corporate-Governance/default.aspx\%0A.

Cogenera México. 2012. "Cogenera México.” 2012. http://www.cogeneramexico.org.mx/.

Comisión Nacional para el Uso Eficiente de la Energía (CONUEE), Comisión Reguladora de Energía (CRE), and Gesellschaft für Technische Zusammenarbeit (GTZ). 2009. "Estudio Sobre Cogeneración En El Sector Industrial En México."

http://www.cogeneramexico.org.mx/anexos/2009-12-Cogen_sec-ind-Mex[1].pdf.

Comisión Reguladora de Energía. 2011. Resolución Por La Que La Comisión Reguladora de Energía Expide La Metodología Para El Cálculo de La Eficiencia de Los Sistemas de Cogeneración de Energía Eléctrica Y Los Criterios Para Determinar La Cogeneración Eficiente. RES/003/2011. Mexico: Diario Oficial de la Federación.

http://www.dof.gob.mx/nota_detalle.php?codigo=5178907\&fecha=22/02/2011.

. 2012. Resolución Por La Que La Comisión Reguladora de Energía Expide Las Disposiciones Generales Para Acreditar Sistemas de Cogeneración Como de Cogeneración Eficiente.

RES/291/2012. Mexico: Diario Oficial de la Federación. 
http://www.dof.gob.mx/nota_detalle.php?codigo=5270224\&fecha=26/09/2012.

. 2014. RESOLUCIÓN Por La Que Se Modifica La Diversa Por El Que Se Emitió La Metodología Para El Cálculo de La Eficiencia de Los Sistemas de Cogeneración de Energía Eléctrica Y Los Criterios Para Determinar La Cogeneración Eficiente. RES/206/2014. Mexico: Diario Oficial de la Federación. http://www.dof.gob.mx/nota_detalle.php?codigo=5348183\&fecha=12/06/2014.

. 2015a. Resolucion Por La Que La Comisión Reguladora de Energía ... de La Solicitud de Permisos de Generación de Energía Eléctrica RES/182/2015. Mexico: Diario Oficial de la Federación. http://www.dof.gob.mx/nota_detalle.php?codigo $=5388235 \&$ fecha $=08 / 04 / 2015$.

- 2015b. RESOLUCIÓN Por La Que La Comisión Reguladora de Energía Expide El Modelo de Contrato de Interconexión ... RES/949/2015. Mexico: Diario Oficial de la Federación. http://dof.gob.mx/nota_detalle.php?codigo $=5424297 \&$ fecha $=03 / 02 / 2016$.

. 2016a. "Preguntas Frecuentes Para Obtener La Acreditación Como de Cogeneración Eficiente." 2016. https://www.gob.mx/cre/articulos/preguntas-frecuentes-para-obtener-la-acreditacion-comode-cogeneracion-eficiente.

. 2016b. "Preguntas Frecuentes Sobre La Obtención de Un Permiso Para Generar Energía Eléctrica." 2016. https://www.gob.mx/cre/articulos/preguntas-frecuentes-sobre-la-obtencion-de-unpermiso-para-generar-energia-electrica.

—. 2016c. "Preguntas Frecuentes Sobre Los Certificados de Energías Limpias." 2016. https://www.gob.mx/cre/articulos/preguntas-frecuentes-sobre-los-certificados-de-energias-limpias.

—. 2016d. Resolución ... Los Criterios de Eficiencia Y Establecen La Metodología de Cálculo Para Determinar El Porcentaje de Energía Libre de Combustible En Fuentes ... de Energía Eléctrica RES/1838/2016. Mexico: Diario Oficial de la Federación. http://www.dof.gob.mx/nota_detalle.php?codigo=5466651\&fecha=22/12/2016.

—. 2017a. Resolucion de La Comisión Reguladora de Energía ... Aplicables a Las Centrales Eléctricas de Generación Distribuida Y Generación Limpia Distribuida. RES/142/2017. Mexico: Diario Oficial de la Federación. http://www.dof.gob.mx/nota_detalle.php?codigo=5474790\&fecha=07/03/2017.

— 2017b. "Tabla de Permisos de Generación E Importación de Energía Eléctrica Administrados Al 31 de Octubre de 2017.” 2017.

https://web.archive.org/web/20180308205013/https://www.gob.mx/cms/uploads/attachment/file/273 395/INFO_PAGINA_2017-10-31_-_1TablaPermisos.pdf.

_. 2018. “Tabla de Permisos de Generación E Importación de Energía Eléctrica Administrados Al 30 de Abril de 2018." 2018.

https://web.archive.org/web/20180608160352/https://www.gob.mx/cms/uploads/attachment/file/323 655/INFO_PAGINA_2018-04-30_-_1TablaPermisos.pdf.

Congreso de la Unión. 2015. Ley de Transición Energética. Mexico. http://dof.gob.mx/nota_detalle.php?codigo=5421295\&fecha=24/12/2015.

Deign, Jason. 2017. "The World's Cheapest Solar Bid Is Actually for Wind.” Greentech Media, November 26, 2017. https://www.greentechmedia.com/articles/read/the-worlds-cheapest-solar-isactually-wind-mexico\#gs.3tjX1iU.

Deloitte. 2016. "FIBRA E, CerPI Y FICAP: 3 Propuestas Sobresalientes Para La Infraestructura Energética." https://www2.deloitte.com/content/dam/Deloitte/mx/Documents/tax/FinanciamientoEnergetico-FibraE.pdf.

Dyer, Dwight. 2017. “Mexico's CENAGAS First Open Season Is Mixed Bag.” NGI’s Daily Gas Price 
Index, April 4, 2017. http://www.naturalgasintel.com/articles/110000-mexicos-cenagas-first-openseason-is-mixed-bag.

Energía, Secretaría de. 2016. "Nutrida Participación En La Fase Inicial de La Primera Subasta de Largo Plazo Del Mercado Eléctrico." 2016. https://www.gob.mx/sener/prensa/nutrida-participacion-en-lafase-inicial-de-la-primera-subasta-de-largo-plazo-del-mercado-electrico.

Export-Import Bank of the United States. n.d. "Energy Efficiency and End-Use Energy Efficiency Exports." EXIM Bank and the Environment. Accessed March 9, 2018. https://www.exim.gov/policies/ex-im-bank-and-the-environment/energy-efficiency-and-end-useenergy-efficiency-exports.

Flores-Espino, Francisco, Sarah Booth, and Andrew Graves. 2017. "Mexico's Geothermal Market Assessment Report.” https://doi.org/10.2172/1349719.

Grageda Nunez, Eugenio. 2015. “Mexican Tax Reforms for 2016.” Greenberg Traurig. 2015. https:/www.lexology.com/library/detail.aspx?g=c08d8029-b00b-4d83-b06d-1437b812d551.

Groenewold, Manual. 2012. "Sourcing Capital through Mexico's CKD Structure: The Next Phase." EMPEA Legal \& Regulatory Bulletin. http://www.latinfinance.com/Article/3755798/Investorsgrowing-confident-about-Mexicos-Fibra-E.html\#/.Wdt_UGiPKck.

Grupo BMV. n.d. "Fideicomisos de Infraestructura Y Bienes Raices." https://www.bmv.com.mx/docspub/MI_EMPRESA_EN_BOLSA/CTEN_MINGE/Fibras.pdf.

International Energy Agency. 2017. "Mexico Capacity and Power Auctions Supported by Clean Energy Certificates." IEA Policies and Measures Mexico. 2017.

http://www.iea.org/policiesandmeasures/pams/mexico/name-160912-en.php.

KPMG. 2016. "Opportunities in the Mexican Electricity Sector." https://assets.kpmg.com/content/dam/kpmg/mx/pdf/2016/09/Opportunities-in-the-MexicanElectricity-Sector.pdf.

LatinFinance. 2017. “Investors Growing Confident about Mexico's Fibra-E.” LatinFinance, October 2, 2017. http://www.latinfinance.com/Article/3755798/Investors-growing-confident-about-MexicosFibra-E.html\#/.Wdt_UGiPKck.

Martínez, Guillermo Zúñiga. 2015. "Reform of the Mexican Energy Sector During 2013 and 2014." https:/www.gob.mx/cms/uploads/attachment/file/13744/DesarrolloRegulacion.pdf.

- 2016. "Advances on the Implementation of the Electricity Reform in Mexico." http://sites.utexas.edu/kbhenergycenter/files/2016/03/Zuniga-Presentación-CIDAC-CRE-Final.pdf.

Mordor Intelligence. 2017. "Mexico Combined Heat and Power (CHP) MARKET - Prepared for ORNL."

Mosseri, Juan. 2018. "Personal Communication from Juan Mosseri (Capstone Turbines) to Elena Berger, 24 August 2018."

OHL Industrial. 2015. "OHL Industrial and SENER Awarded a Contract to Build the Empalme I Combined Cycle Power Plant in Mexico for 445 Million Euro.” 2015. http://www.ohl.es/en/pressroom/news/2015/april-2015/150416-ohl-industrial-and-sener-awarded-a-contract-to-build-theempalme-i-combined-cycle-power-plant-in-mexico-for-445-million-euro/.

Overseas Private Investment Corporation. 2018. "All Projects Descriptions.” OPIC in Action. 2018. https://www.opic.gov/opic-action/all-project-descriptions.

Power Technology. n.d. "Nuevo Pemex Cogeneration Power Plant, Tabasco." Accessed March 9, 2018. http://www.power-technology.com/projects/nuevo-pemex-cogeneration-power-plant-tabasco/.

Robles, Alejandro Chanona. 2016. "Tracking the Progress of Mexico's Power Sector Reform." Wilson 
Center-Mexico Institute.

https://www.wilsoncenter.org/sites/default/files/tracking_progress_of_mexicos_power_sector_refor m.pdf.

Secretaría de Energía de México. 2015. "Programa de Desarrollo Del Sistema Eléctrico Nacional 20152029." https://www.gob.mx/sener/acciones-y-programas/programa-de-desarrollo-del-sistemaelectrico-nacional-33462.

- 2016a. "Inversión de 4 Mil Millones de Dólares Al Concluir El Proceso de La Segunda Subasta Eléctrica.” 2016. https://www.gob.mx/sener/prensa/inversion-de-4-mil-millones-de-dolares-alconcluir-el-proceso-de-la-segunda-subasta-electrica-69919?idiom=es.

_ 2016b. "Programa de Desarrollo Del Sistema Eléctrico Nacional 2016-2030." https://www.gob.mx/sener/acciones-y-programas/programa-de-desarrollo-del-sistema-electriconacional-33462.

_. 2016c. "Prospectiva Del Sector Eléctrico 2016-2030."

https://www.gob.mx/cms/uploads/attachment/file/177626/Prospectiva_del_Sector_El_ctrico_20162030.pdf.

_ 2017a. "Energy Information System: Electricity National Balance." 2017. http://sie.energia.gob.mx/bdiController.do?action=cuadro\&cvecua=IIE5C22.

_ 2017b. "Energy Information System: National Energy Balance: Final Energy Consumption by Sector." 2017. http://sie.energia.gob.mx/bdiController.do?action=cuadro\&cvecua=IIE4C02.

_. 2017c. "Programa de Desarrollo Del Sistema Eléctrico Nacional 2017 - 2031." https://www.gob.mx/sener/acciones-y-programas/programa-de-desarrollo-del-sistema-electriconacional-33462.

—. 2018. "Programa de Desarrollo Del Sistema Eléctrico Nacional 2018-2032." https://www.gob.mx/sener/acciones-y-programas/programa-de-desarrollo-del-sistema-electriconacional-33462.

Secretaría de Gobernación. 2016. ACUERDO Por El Que Se Emite El Manual de Interconexión de Centrales de Generación Con Capacidad Menor a 0.5 MW. Mexico: Diario Oficial de la Federación. http://www.dof.gob.mx/nota_detalle.php?codigo=5465576\&fecha=15/12/2016.

Serra, Juan Carlos, and Jorge Edardo Escobedo. 2017. "Electricity Regulation in Mexico: Overview." Thomas Reuters Practical Law. 2017.

https:/content.next.westlaw.com/Document/Ieb49d7bc1cb511e38578f7ccc38dcbee/View/FullText. html contextData $=($ sc.Default $) \&$ transitionType $=$ Default\& firstPage $=$ true $\& b h c p=1$.

"The Money Converter." 2018. 2018. https://web.archive.org/web/20180306214757/https://themoneyconverter.com/MXN/USD.aspx.

Vietor, Richard H.K., and Haviland Sheldahl-Thomason. 2017. "Mexico's Energy Reform.” Harvard Business School January (Case 717-027). https://sites.hks.harvard.edu/hepg/Papers/2017/Mexican Energy Reform Draft 1.23.pdf. 


\section{APPENDIX A. DESCRIPTION OF CHP SYSTEM}

Combined heat and power is an efficient and clean approach to generating power and thermal energy from a single fuel source and is used either to replace or supplement conventional separate heat and power (SHP). Instead of purchasing electricity from the local utility and burning fuel in an on-site furnace or boiler to produce needed steam or hot water, an industrial or commercial user can use CHP to provide both energy services in one energy-efficient step. Every CHP application involves the recovery of thermal energy that would otherwise be wasted to produce additional power or useful thermal energy; as such, CHP can provide significant energy efficiency and environmental advantages over SHP. It is reasonable to expect CHP applications to operate at $65 \%$ to $75 \%$ efficiency, a significant improvement over the average of $40 \%$ to $50 \%$ for these services when separately provided.

Combined heat and power can be configured either as a topping or bottoming cycle. In a topping cycle, fuel is combusted in a prime mover such as a gas turbine or reciprocating engine, generating electricity or mechanical power. Energy normally lost in the prime mover's hot exhaust and/or cooling systems is recovered to provide process heat, hot water, or space heating/cooling for the site. ${ }^{7}$ In a bottoming cycle, also referred to as waste heat to power, fuel is combusted to provide thermal input to a furnace or other industrial process, and some of the heat rejected from the process is then used for power production. For optimal efficiency, CHP systems are typically designed and sized to meet a facility's baseload thermal demand.

Combined heat and power is a distributed energy resource that is, by definition, strategically located at or near the point of energy use. While existing CHP capacity in Mexico is mostly located at industrial facilities, [75\% of existing CHP capacity in 2016 was located in industrial applications (Mordor Intelligence 2017)], CHP can also be an attractive resource for schools and hospitals, in district energy systems, and other applications. Such on-site generation avoids the T\&D losses associated with electricity purchased via the grid from central stations and defers or eliminates the need for new T\&D investment. The inherent higher efficiency and elimination of T\&D losses from the central station generator results in reduced primary energy use and lower GHG emissions.

The increase in fuel use efficiency of CHP combined with the use of lower carbon fuels such as natural gas generally translates into reductions in GHG and criteria emissions compared to separate heat and power. Considering its higher capacity factor, $\mathrm{CHP}$ can provide overall energy and $\mathrm{CO}_{2}$ savings on par with comparably sized solar photovoltaics (PV), wind, and natural gas combined-cycle systems (NGCC) producing power only; with the additional benefit of a much smaller footprint required for the same size power generation.

\footnotetext{
${ }^{7}$ In another version of a topping cycle, fuel is burned in a boiler to produce high-pressure steam. That steam is fed to a steam turbine, generating mechanical power or electricity before exiting the turbine at lower pressure and temperature, and used for process or heating applications at the site.
} 



\section{APPENDIX B. FORMS AND DOCUMENTATION NEEDED TO GAIN A PERMIT FOR ELECTRICITY GENERATION, EFFICIENT COGENERATION ACCREDITATION, AND INTERCONNECTION}

Table B.1. Online application form for a permit to generate electricity.

\begin{tabular}{ll}
\hline \multicolumn{1}{c}{ Header } & \multicolumn{1}{c}{ Key details } \\
\hline Applicant Details & Name and identifying information of applicant and legal representative \\
\cline { 2 - 2 } & Address and contact information of applicant and for notifications \\
\hline Data of inscription of Public Registry of Property and Commerce \\
\hline Electric Power Plant Data & Address and contact information \\
\cline { 2 - 2 } & $\begin{array}{l}\text { Type of technology in power plant } \\
\text { Gross generation capacity (AC or DC) }\end{array}$ \\
\cline { 2 - 2 } & Estimated annual electricity generation \\
\hline Fuels Used by the Power Plant & Type, consumption, lower heating value, cost, name of source, transportation \\
\hline Other Documentation & See next table \\
\hline More Information & $\underline{\text { https://www.gob.mx/cre/articulos/preguntas-frecuentes-sobre-la-obtencion-de- }}$ \\
& $\underline{\text { un-permiso-para-generar-energia-electrica }}$ \\
\hline https://www.gob.mx/cre/acciones-y-programas/micrositio-de-permisos-en- \\
\hline
\end{tabular}


Table B.2. Online application form for a permit to generate electricity - additional documents.

Other required documentation

Details

Applicant Official

Paperwork
Identification information for applicants, including official documents (such as birth certificates and official Mexican ID) (natural persons) or articles of incorporation and bylaws (legal persons)

\begin{tabular}{|c|c|}
\hline Legal Representative & Legal representative identification information and Power of Attorney \\
\hline \multirow{5}{*}{$\begin{array}{l}\text { General Project } \\
\text { Description }\end{array}$} & Proposed location, \\
\hline & Interconnection points \\
\hline & Single-line diagram of power plant(s) and interconnection points \\
\hline & Capacity and estimated annual generation \\
\hline & Type of generation technology (and fuel, if applicable) \\
\hline \multirow[t]{2}{*}{$\begin{array}{l}\text { Proof of Applicant's } \\
\text { Financial and Technical } \\
\text { Capability } \\
\text { to Construct the Plant } \\
\text { and Provide Electricity }\end{array}$} & $\begin{array}{l}\text { Financial proof can include } \\
\text { - } \quad \text { general description and outline of the project financing plan } \\
\text { - } \quad \text { general description of capital contributions } \\
\text { - } \quad \text { general description of the financing credit plan }\end{array}$ \\
\hline & $\begin{array}{l}\text { Technical proof should include } \\
\text { information on the construction/installation company showing their experience on } \\
\text { similar projects } \\
\text { - } \quad \text { contract/letter of intent between applicant and construction/installation company }\end{array}$ \\
\hline \multirow{5}{*}{$\begin{array}{l}\text { Social Impact } \\
\text { Assessment } \\
\text { (Application or Results) }\end{array}$} & The description of the project and its area of influence \\
\hline & $\begin{array}{l}\text { Identification and characterization of communities and villages that are located in the } \\
\text { area of influence of the project }\end{array}$ \\
\hline & $\begin{array}{l}\text { The identification, characterization, prediction, and evaluation of the positive and } \\
\text { negative social impacts that could be derived from the project }\end{array}$ \\
\hline & Prevention and mitigation measures and social management plans \\
\hline & This process is free but will take up to 90 calendar days \\
\hline Business Information & $\begin{array}{l}\text { Information regarding the investment of the project, internal rate of return, operating and } \\
\text { maintenance costs, capital flows, etc. }\end{array}$ \\
\hline Proof of Payment & Dependent on size of plant (free for renewables, but not for fuel-based cogeneration) \\
\hline May Also Require & $\begin{array}{l}\text { Federal environmental permits, local/municipal authority permits (environmental, land } \\
\text { use, civil protection, etc.) }\end{array}$ \\
\hline More Information & $\begin{array}{l}\text { Permits and supporting documentation: } \\
\text { https://www.gob.mx/tramites/ficha/permiso-para-generar-energia-electrica/CRE2151 } \\
\text { https://www.gob.mx/cre/articulos/preguntas-frecuentes-sobre-la-obtencion-de-un- } \\
\text { permiso-para-generar-energia-electrica } \\
\text { Social impact assessment: } \\
\text { https://www.gob.mx/tramites/ficha/evaluacion-de-impacto-social/SENER2561 }\end{array}$ \\
\hline
\end{tabular}


Table B.3. Interconnection studies details.

\begin{tabular}{|c|c|}
\hline Type of study & Details \\
\hline \multirow[t]{2}{*}{1 - Indicative } & Feasibility of the Project \\
\hline & $\begin{array}{l}\text { https://www.gob.mx/tramites/ficha/estudio-indicativo-para-la-interconexion-de- } \\
\text { centrales-electricas-mayores-a-10-mw/CENACE3371 }\end{array}$ \\
\hline \multirow[t]{2}{*}{2 - Impact } & Determine the infrastructure requirements for interconnection \\
\hline & $\begin{array}{l}\text { https://www.gob.mx/tramites/ficha/estudio-de-impacto-en-el-sistema-para-la- } \\
\text { interconexion-de-centrales-electricas-mayores-a-10-mw/CENACE3399 }\end{array}$ \\
\hline \multirow[t]{2}{*}{3 - Installation } & $\begin{array}{l}\text { Characterizes elements and equipment, estimates cost of interconnection and } \\
\text { reinforcements to the network }\end{array}$ \\
\hline & $\begin{array}{l}\text { https://www.gob.mx/tramites/ficha/estudio-de-instalaciones-para-la-interconexion- } \\
\text { de-centrales-electricas-mayores-a-10-mw/CENACE3368 }\end{array}$ \\
\hline \multirow[t]{2}{*}{ Between $500 \mathrm{~kW}-10 \mathrm{MW}$} & $\begin{array}{l}\text { May be able to do "quick" interconnection studies with simplified Impact and } \\
\text { Installation Studies }\end{array}$ \\
\hline & $\begin{array}{l}\mathrm{https}: / \text { www.gob.mx/tramites/ficha/estudio-de-impacto-en-el-sistema-version-rapida- } \\
\text { e-instalaciones-para-la-interconexion-de-pequenas-centrales-electricas-con- } \\
\underline{\text { capacidad-de-generacion-de-0-5-mw-a-10-mw/CENACE3400 }}\end{array}$ \\
\hline \multirow[t]{2}{*}{ If Less than $500 \mathrm{~kW}$} & May not need interconnection studies, and they may have no cost \\
\hline & $\begin{array}{l}\text { https://www.gob.mx/tramites/ficha/interconexion-de-centrales-electricas-con- } \\
\text { capacidad-menor-a-0-5-mw/CFE3143 }\end{array}$ \\
\hline
\end{tabular}

Table B.4. Form CRE-DGEER-011: Application for the permit holder of a cogeneration plant to obtain accreditation as efficient cogeneration.

\begin{tabular}{|c|c|}
\hline Header & Key details \\
\hline \multirow[t]{3}{*}{ Details of Cogeneration Permit } & Name of holder \\
\hline & Name of legal representative \\
\hline & Permit number \\
\hline Details of Cogeneration Plant & Address/contact information \\
\hline \multirow{5}{*}{$\begin{array}{l}\text { Information on Cogeneration } \\
\text { System }\end{array}$} & Energy Variables (E, H, F, as applicable) \\
\hline & $\begin{array}{l}\text { Type of Cogeneration plant } \\
\text { - } \quad \text { Produces electricity and steam/other thermal } \\
\text { - } \quad \text { Direct/indirect electricity from unused thermal } \\
\text { - } \quad \text { Direct/indirect electricity from fuels generated by process }\end{array}$ \\
\hline & Name of operator of process leading to cogeneration \\
\hline & $\begin{array}{l}\text { Main equipment in cogeneration system including boilers, prime movers, } \\
\text { electric generations (name and number) }\end{array}$ \\
\hline & Number of measurement points \\
\hline \multirow[t]{2}{*}{ Information for Accreditation } & First time applying, renewal, change of conditions \\
\hline & Operations start date \\
\hline \multirow[t]{3}{*}{ Other Required Documentation } & Power of Attorney for legal representation \\
\hline & $\begin{array}{l}\text { Free form letter to CRE on any changes in technical specification from what } \\
\text { was originally covered by generation permit }\end{array}$ \\
\hline & Diagram of cogeneration process with proposed measurement points \\
\hline For More Information & $\begin{array}{l}\text { https://www.gob.mx/cre/articulos/preguntas-frecuentes-para-obtener-la- } \\
\text { acreditacion-como-de-cogeneracion-eficiente }\end{array}$ \\
\hline
\end{tabular}


Table B.5. Form CRE-DGEER-012: Application to authorize a person doing the measurement to measure variables in cogeneration systems.

\begin{tabular}{|c|c|}
\hline Header & Key details \\
\hline \multirow[t]{4}{*}{ Applicant Data } & Name of holder \\
\hline & Address/contact information \\
\hline & Registration data in Public Registry of Property and Commerce \\
\hline & Name of legal representative \\
\hline Authorization Information & First time applying, renewal, change of conditions \\
\hline \multirow[t]{4}{*}{ Other Required Documentation } & Accreditation of application \\
\hline & Power of Attorney for legal representation \\
\hline & Name, academic background, experience, and training of applicant \\
\hline & $\begin{array}{l}\text { Inventory of equipment demonstrating that they have sufficient infrastructure } \\
\text { to provide the measurement services requested by the permit holders and the } \\
\text { valid calibration certificates issued by an authorized institution }\end{array}$ \\
\hline For more information & $\begin{array}{l}\text { https://www.gob.mx/cre/articulos/preguntas-frecuentes-para-la-autorizacion- } \\
\text { de-medicion-de-variables-de-cogeneracion }\end{array}$ \\
\hline
\end{tabular}


Table B.6. Form CRE-DGEER-013: Technical reporting format for parameters for the calculation of efficiency of cogeneration systems.

\begin{tabular}{|c|c|}
\hline Header & Key details \\
\hline \multirow{2}{*}{$\begin{array}{l}\text { Data for person authorized to } \\
\text { measure cogeneration systems }\end{array}$} & Name \\
\hline & Address and contact information \\
\hline \multirow[t]{4}{*}{ Data for the permit holder } & Name \\
\hline & Cogeneration permit number \\
\hline & Name of legal representative \\
\hline & Address of cogeneration plant \\
\hline \multirow[t]{7}{*}{ Technical data } & $\begin{array}{l}\text { Type of cogeneration plant } \\
\text { - } \quad \text { Produces electricity and steam/other thermal } \\
\text { - } \quad \text { Direct/indirect electricity from unused thermal } \\
\text { - } \quad \text { Direct/indirect electricity from fuels generated by process }\end{array}$ \\
\hline & 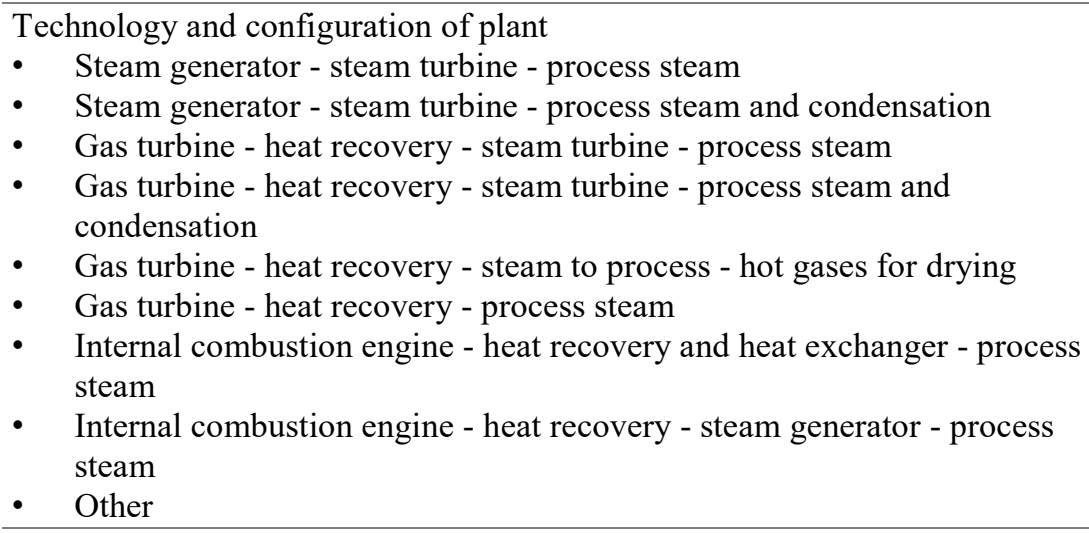 \\
\hline & Max gross generation capacity and estimated annual generation \\
\hline & Fuels used in cogeneration (if applicable) \\
\hline & Description of the process that the cogeneration process provides heat to \\
\hline & Post-combustion devices (if any) \\
\hline & Heat supply devices or other devices (if any) \\
\hline \multirow[t]{6}{*}{ System measurement } & Number of measurement points \\
\hline & $\begin{array}{l}\text { Diagram of the cogeneration system and measurement points of energy } \\
\text { variables }\end{array}$ \\
\hline & Duration of tests \\
\hline & $\begin{array}{ll}\text { Fuel consumed } \\
\text { - } & \text { For cogeneration } \\
\text { - } & \text { By post-combustion devices } \\
\text { - } & \text { For other equipment that provides heat to the process } \\
\end{array}$ \\
\hline & Generated electricity \\
\hline & $\begin{array}{l}\text { Useful heat } \\
\text { - Total delivered to the process } \\
\text { - } \quad \text { Supplied by post-combustion devices } \\
\text { - } \quad \text { Provided by other devices }\end{array}$ \\
\hline \multirow[t]{3}{*}{ Verification of visit } & Date \\
\hline & Equipment used for measuring fuel and electricity \\
\hline & Method of useful heat measurement (direct or indirect) \\
\hline \multirow[t]{3}{*}{ Other required documentation } & Process diagram and thermal balance \\
\hline & Proof of calibration of measurement equipment \\
\hline & Official paperwork for authorized person performing the measurements \\
\hline
\end{tabular}





\section{APPENDIX C. CONTACTS IN KEY ORGANIZATIONS}

\begin{tabular}{|c|c|c|c|c|}
\hline Organization & Name & Position & Phone \# & Email \\
\hline Cogenera & $\begin{array}{l}\text { Jorge } \\
\text { Armando } \\
\text { Gutiérrez }\end{array}$ & Presidente & $+52(55) 5279-6545$ & Jgutierrez@bal.com.mx \\
\hline $\begin{array}{l}\text { Nafinsa - } \\
\text { Development bank }\end{array}$ & $\begin{array}{l}\text { Gabriela } \\
\text { Larenas Ruiz }\end{array}$ & $\begin{array}{l}\text { Director of } \\
\text { Sustainability } \\
\text { Projects }\end{array}$ & $+52(55) 5325-6365$ & gilarenas@nafin.gob.mx \\
\hline $\begin{array}{l}\text { SENER - Ministry } \\
\text { of Energy }\end{array}$ & $\begin{array}{l}\text { Fernando } \\
\text { Zendejas }\end{array}$ & $\begin{array}{l}\text { Electricity } \\
\text { Under- } \\
\text { Secretary }\end{array}$ & $\begin{array}{l}+52(55) 5000- \\
6000 \text { Ext } 1037\end{array}$ & fzendejas@energia.gob.mx \\
\hline ProMexico - & $\begin{array}{l}\text { Erika Salazar } \\
\text { Sugich }\end{array}$ & $\begin{array}{l}\text { Energy and } \\
\text { Environmental } \\
\text { Technologies } \\
\text { Coordinator }\end{array}$ & $\begin{array}{l}+52(55) 5447-7000, \\
\text { Ext. } 1240\end{array}$ & erika.salazar@promexico.gob.mx \\
\hline $\begin{array}{l}\text { CRE - Energy } \\
\text { Regulatory } \\
\text { Commission }\end{array}$ & $\begin{array}{l}\text { Eduardo René } \\
\text { Narváez } \\
\text { Torres }\end{array}$ & $\begin{array}{l}\text { Clean Energy } \\
\text { Regulation } \\
\text { Director }\end{array}$ & $+52(55)$ 5283-1500 & enarvaez@cre.gob.mx \\
\hline $\begin{array}{l}\text { CENACE - } \\
\text { National Center for } \\
\text { Energy Control }\end{array}$ & $\begin{array}{l}\text { Daniela Diaz } \\
\text { Garduño }\end{array}$ & $\begin{array}{l}\text { Market } \\
\text { Director } \\
\text { Assistant }\end{array}$ & $+52(55) 5724-5860$ & Daniala.diaz@cenace.gob.mx \\
\hline $\begin{array}{l}\text { U.S. Department of } \\
\text { Energy-Mexico } \\
\text { Desk }\end{array}$ & $\begin{array}{l}\text { Kimberly } \\
\text { Ballou }\end{array}$ & Mexico Desk & (202) 586-6029 & Kimberly.Ballou@hq.doe.gov \\
\hline $\begin{array}{l}\text { U.S. Department of } \\
\text { Commerce } \\
\text { International } \\
\text { Trade } \\
\text { Administration }\end{array}$ & Leslie Wilson & Mexico Desk & (202) 482-0704 & Leslie.Wilson@trade.gov \\
\hline $\begin{array}{l}\text { U.S. Embassy in } \\
\text { Mexico }\end{array}$ & $\begin{array}{l}\text { Ramon } \\
\text { Escobar }\end{array}$ & Energy Officer & $+52(55) 5080-2870$ & EscobarRJ@state.gov \\
\hline $\begin{array}{l}\text { U.S. Export Import } \\
\text { Bank }\end{array}$ & $\begin{array}{l}\text { Craig } \\
\text { O'Connor }\end{array}$ & $\begin{array}{l}\text { Director, } \\
\text { Office of } \\
\text { Renewable } \\
\text { Energy \& } \\
\text { Environmental } \\
\text { Exports }\end{array}$ & (202) 565-3556 & craig.oconnor@exim.gov \\
\hline $\begin{array}{l}\text { U.S. Overseas } \\
\text { Private Investment } \\
\text { Corporation }\end{array}$ & Nadia Rhazi & $\begin{array}{l}\text { Global Energy } \\
\text { Group Program } \\
\text { Manager }\end{array}$ & (202) 357-3912 & Nadia.Rhazi@opic.gov \\
\hline $\begin{array}{l}\text { U.S. Trade and } \\
\text { Development } \\
\text { Agency }\end{array}$ & $\begin{array}{l}\text { Peter } \\
\text { Greenwood }\end{array}$ & $\begin{array}{l}\text { Country } \\
\text { Manager for } \\
\text { Mexico }\end{array}$ & $703-875-4357$ & pgreenwood@ustda.gov \\
\hline $\begin{array}{l}\text { U.S. Commercial } \\
\text { Service }\end{array}$ & $\begin{array}{l}\text { Claudia } \\
\text { Salgado }\end{array}$ & $\begin{array}{l}\text { Commercial } \\
\text { Specialist }\end{array}$ & $+52(55) 4450-0472$ & Claudia.Salgado@trade.gov \\
\hline $\begin{array}{l}\text { Inter-American } \\
\text { Development Bank }\end{array}$ & Enrique Nieto & $\begin{array}{l}\text { Financial } \\
\text { Markets Lead } \\
\text { Specialist }\end{array}$ & (202) 623-2340 & enriquen@iadb.org \\
\hline
\end{tabular}

